\title{
CURRENT LITERATURE IN EXPERIMENTAL PSYCHOLOGY
}

\section{METHODS \& INSTRUMENTATION}

\section{METHODS AND DESIGNS}

Batchelder. W. H. (Sch. of Soc. Sci., Univ. of California, Irvine, Calif. 92664). Individual differences and the all-or-none is incremental learning controversy. Joumal of Mathematical Psychology, 1975, 12. 53-74.

Collewijn, H. (Dept. of Physiol., Faculty of Med., Erasmus Univ., Rotterdam, The Netherlands), van DER MARK, F., \& JANSEN. T. C. Precise recording of human eye movements. Vision Re'search. 1975, 15, 447-450.

Kotlyarsky, A. M. (Helmholtz Inst. of Ophthalmol., Moscow, USSR). \& ZhiLkin, A. M. A new method for stabilizing the position of retinal images. Vision Research, $1975,15,337-339$.

Krantz, D. H. (Univ. of Michigan, Ann Arbor, Mich. 48104), \& TVERSKY, A. Similarity of rectangles: An analysis of subjective dimensions. Journal of Mathematical Psychology, $1975,12,4-34$.

Krausman. D. T. (Div. of Behav. Biol., Johns Hopkins Univ.. Sch. of Med.. 720 Rutland Ave., Baltimore, Md. 21205). Methods and procedures for monitoring and recording blood pressure. American Psychologist, 1975. 30. 285-294.

Monty. R. A. (Behav. Rsch. Directorate. U.S. Army Human Eng. Lab.. Aberdeen Proving Ground, Md. 21005). An advanced eye-movement measuring and recording system. Americun Psychologist. 1975, 30. 331-335.

Obrist, P. A. (Div. of Hlth. Affairs, Sch. of Med., Dept. of Psychiat., Chapel Hill, N.C. 27514), Gaebelein, C. J., \& Langer, A. W. Cardiovascular psychophysiology: Some contemporary methods of measurement. American Psychologist, 1975, 30. 277-284.

O'Leary, K. D. (SUNY, Stony Brook, N.Y. 11794), Kent, R. N., \& Kanowitz, J. Shaping data collection congruent with experimental hypotheses. Journal of Applied Behavior Analysis. $1975,8.43-51$

Roeser, R. J. (Callier Ctr. for Communication Disorders \& Hlth Sci. Ctr., Univ. of Texas, 1966 Inwood Rd., Dallas, Tex. 75235), \& Glorig, A. Pure tone audiometry in noise with auraldomes. Audiology, 1975, 14, 144-151.

Sandler, H. (Chief, Biomed. Rsch. Div., Mail Stop N-239-8, NASA, Ames Rsch. Ctr., Moffett Field, Calif. 94035), McCutcheon, E. P., Fryer, T. B., Rositano, S., Westbrook, R., \& Haro, P. Recent NASA contributions to biomedical telemetry. American Psychologist, 1975, 30, 257-264.

Young, L. R. (Dept. of Aeronautics \& Astronautics, M.I.T. Cambridge, Mass. 02139), \& Shenna, D. Eye-movement measurement techniques. American Psychologist, 1975, 30. 315-330.

\section{INSTRUMENTATION AND TECHNIQUES}

Cooper. W. A. (Dept. of Audiol. \& Sp. Sci.. Purdue Univ. West Lafayette, Ind. 47907), Franks, J. R., McFall, R. N.. \& Goldstein, D. P. Variable venting valve for earmolds. Audiology, 1975, 14, 259-267.

Delgado, J. M. R. (Departmento de Ciencias Fisiologicas. Facultad de Medicina Universidad Autonoma, Herederos de Navas, 1, Madrid-34, Spain), Lipponen, V., Weiss, G.. Del Pozo, F., Monteagudo, J. L., \& McMahon, R. Two-way transdermal communication with the brain. Americun Psychologist, 1975, 30. 265-273.
Fried, R. (Hunter Coll. of CUNY, New York, N.Y. 10021). A siniple additive color mixer for exploration of the color solid. Bulletin of the Psychonomic Society, 1975, 5. 325-326.

Guld, C. (Inst. of Neurophysiol.. Univ. of Copenhagen. Copenhagen. Denmark), \& Bertulis, A. Contact lenses for animals used in vision resear ${ }^{-h}$. Vision Research, 1975, 15. $441-442$.

Leibowitz, H. W. (417 Bruce V. Moore Bldg., Pennsylvania State Univ., University Park, Pa. 16802), \& Hennessy, R. T. The laser optometer and some implications for behavioral research. American Psychologist. 1975, 30, 349-352.

Olsen, W. (Mayo Clinic, Rochester, N.Y. 55901), \& Carhart, R. Head diffraction effects on ear-level hearing aids. Audiology, 1975, 14, 244-258.

Patterson, M. M. (Dept. of Physiol., Kirksville Coll. of Osteopathic Med., Kirksville. Mo. 63501). Instrumentation and techniques in physiological psychology. American Psychologist, 1975, 30, 249-256.

Pickens, R. (Psychiat. Rsch. Unit, Box 392 Mayo, Univ. of Minnesota, Minneapolis, Minnesota 55455), \& Thompson, T. Intravenous preparations for self-administration of drugs by animals. American Psychologist, 1975, 30, 274-276.

Polley, E. H. (Depts. of Anat. \& Ophthalmol., Univ. of Illinois Coll. of Med., Chicago, Ill. 60612), APple, D. J.. \& Bizzell, J. W. The laser as a research tool in visual system investigation. American Psychologist, 1975, 30, 340-348.

Sherrick, C. E. (Green Hall, Princeton Univ., Princeton, N.J. 08540). The art of tactile communication. American Psychologist, 1975, 30, 353-360.

Stark, E. W. (Dept. of Speech \& Hrg. Sci., 322 Illini Hall, Univ. of Illinois, Urbana-Champaign, Ill. 61820), \& Borton. T. E. Noise-excluding enclosure for audiometry. Audiology, 1975, 14, 232-237.

Vunderink, R. A. F. (Inst. for Perception TNO, Soesterberg, Kampweg 5. Postbus 23, The Netherlands), \& Sanders, A. F. A wide-screen projection system for human performance studies. American Psychologist, 1975, 30, 336-339.

\section{STATISTICAL TECHNIQUES}

Cliff, N. (Univ. of Southern California, University Park, Los Angeles. Calif. 90007). Complete orders from incomplete data: Interactive ordering and tailored testing. Psychological Bull'tin. 1975, 82, 289-302.

Crawford, C. B. (Simon Fraser Univ., Burnaby 2. B.C., Canada). Determining the number of interpretable factors. Psychological Bulletin, 1975, 82, 226-237.

Golding, S. L. (Univ. of Illinois. Urbana, Ill. 61801). Flies in the ointment: Methodological problems in the analysis of the percentage of variance due to persons and situations. Psychological Bulletin, 1975, 82, 278-288.

LEVY, K. J. (SÜNY, 4230 Ridge Lea Rd., Buffalo. N.Y. 14226). Large-sample pair-wise comparisons involving correlations. proportions, or variances. Psychological Bulletin, 1975, 82, $174-176$

LEvy, K. J. (SUNY, 4230 Ridge Lea Rd., Buffalo, N.Y. 14226). Large-sample many-one comparisons involving correlations, proportions, or variances. Psychological Bulletin. $1975,82,177-179$. 
Ling, R. F. (Univ. of Chicago, Chicago, Ill. 60637). An exact probability distribution on the connectivity of random graphs. Journal of Mathematical Psychology, 1975, 12, 90-98.

Maxwell. S. (L. L. Thurstone Psychometric Lab.. Univ. of North Carolina, Chapel Hill. N.C. 27514), \& CRAMER, E. M. A note on analisis of covariance. Psychological Bulletin. 1975. 82. $187-190$.

Miller, J. K. (Univ. of Rochester. Rochester, N.Y. 14627). In defense of the general canonical correlation index: Reply to Nicewander and Wood. Psychological Bulletin, 1975, 82. 207-209.

Nicewander. W. A. (Univ. of Oklahoma, Norman, Okla. 73069), $\&$ WooD. D. A. On the mathematical bases of the general canonical correlation index: Rejoinder to Miller. Psychological Bulletin. 1975, 82. 210-212.

Overall, J. E. (Psychometric Lab., Univ. of Texas Med. Branch. Galveston. Tex. 77550), Spiegel, D. K., \& Cohen, J. Equivalence of orthogonal and nonorthogonal analysis of variance. Psychological Bulletin, 1975, 82, 182-186.

Polizzotro. L. (103 Lexington St.. Auburndale. Mass. 02166). \& Peura. R. A. A mathematical approach to explain subjective color perception. Vision Research. 1975, 15, 613-616.

Richter. M. K. (Dept. of Economics. Univ. of Minnesota, Minneapolis. Minn. 55455). Rational choice and polynomial measurement models. Joumal of Mathematical Psychology. 1975. 12. 99-113.

SJöвERG. L. (Univ. of Gothenburg, Fack, 40020 Gothenburg 14. Sweden). Models of similarity and intensity. Psychological Bulletin. 1975, 82. 191-206.

\section{COMPUTER TECHNOLOGY}

Bailey, D. E. (Muenzinger E318, CLIPR, Univ. of Colorado, Boulder. Colo. 80302). \& Polson, P. G. Real-time computing in psychology at the University of Colorado. American Psychologist, 1975, 30, 212-218.

Castellan. N. J.. JR. (Indiana Univ., Bloomington, Ind. 47401).
The modern minicomputer in laboratory automation. American Psychologist, 1975, 30. 205-211.

Ciriff. N. (Univ. of Southern California, University Park, Los Angeles. Calif. 90007). Complete orders from incomplete data: Interactive ordering and tailored testing. Psychological Bulletin, 1975, 82, 289-302.

Donchin, E. (Univ. of Illinois, Champaign, Ill. 61820), \& HefFley, E. Minicomputers in the signal-averaging laboratory. American Psychologist, 1975, 30, 299-312.

Fitzhugh, R. J. (Lrng. Rsch. \& Devel. Ctr., Univ. of Pittsburgh, Pittsburgh, Pa. 15260), \& Glaser, R. A general-purpose computer system for a research and development center. American Psychologist, 1975, 30, 219-225.

Gregg, L. W. (Carnegie-Mellon Univ., Pittsburgh, Pa. 15213). Computers: Large-scale usage in the balance. American Psychologist, 1975, 30, 199-204.

KING. J. F. (Illinois State Univ., Normal, Ill. 61761). Time-shared control systems: Promises and problems. American Psychologist, 1975, 30. 226-229.

Reddy, R. (Dept. of Computer Sci., Carnegie-Mellon Univ. Pittsburgh, Pa. 15213), Rosen, B., Kriz, S., Powell, M. \& Broadley, B. Computer graphics in research: Some stateof-the-art systems. American Psychologist, 1975, 30, 239-246.

Roemer, R. A. (Eastern Pennsylvania Psychiat. Inst., Henry $\&$ Abbotsford, Philadelphia, Pa. 19129). Some interactive computer applications in a physiological psychology laboratory. American Psychologist, 1975. 30, 295-298.

Sidow SkI. J. B. (Univ. of South Florida, Tampa, Fla. 33620). Instrumentation and computer technology: Applications and influences in modern psychology. American Psychologist, 1975. 30. 191-196.

Wood, R. W. (Dept. of Radiation Biol. \& Biophysics, Univ. of Rochester Med. Ctr., Rochester, N.Y. 14642), Sette, W. F., \& Weiss, B. Interfacing the experimenter to the computer: Languages for psychologists. American Psychologist, 1975, 30, 230-238.

\section{HUMAN EXPERIMENTAL PSYCHOLOGY}

\section{HUMAN DEVELOPMENTAL CHANGES}

Aitken, P. P., \& Hutt, C. (Univ. of Keele, Keele, Staffs. ST5 5BG, England). The effects of stimulus incongruity upon children's attention, choice, and expressed preference. Journal of Experimental Child Psychology, 1975, 19. 79-87.

Bench, J. (Royal Berkshire Hosp., Reading RG1 5AP, England). Langford, C., \& Wilson. I. Some effects of prestimulus activity and length of prestimulus observation on judgments of infants' auditory behaviour. Audiology, $1975,14,164-172$.

Blake, J. (York Univ., 4700 Keele St., Downsview, 463, Ont., Canada), \& Beilin, $\mathrm{H}$. The development of same and different judgments. Journal of Experimental Child Psychology, 1975. 19. 177-194.

Clinton, L. (Univ. of Illinois, Champaign, Ill. 61820), \& Boyce, K. D. Rule-governed imitative verbal behavior as a function of modeling procedures. Journal of Experimental Child Psychology, 1975, 19. 115-121.

Hendrick, C. (Kent State Univ., Kent, Ohio 44242), Franz, C. M., \& Hoving, K. L. How do children form impressions of persons? They average. Memory \& Cognition, 1975, 3, 325-328.

Kallman, W. M., \& IsaAC, W. (Univ. of Georgia, Athens, Ga. 30602). The effects of age and illumination on the doseresponse curves for three stimulants. Psychopharmacologia (Berlin), 1975, 40, 313-318.

Kellas, G. (Univ. of Kansas, Lawrence, Kans. 66045), McCauley, C., \& McFarland, C. E., JR. Developmental aspects of storage and retrieval. Journal of Experimental Child Psychology, 1975, 19. 51-62.
Kopp, C. B. (Dept. of Pediat., UCLA, Los Angeles, Calif. 90024). Sigman, M., Parmelee, A. H., \& Jeffrey, W. E. Neurological organization and visual fixation in infants at 40 weeks conceptional age. Developmental Psychobiology, 1975, 8, 165-170.

Lubow, R. E. (Tel-Aviv Univ., Ramat-Aviv, Israel), Alek, M., \& ARzY, J. Behavioral decrement following stimulus preexposure: Effects of number of preexposures, presence of a second stimulus, and interstimulus interval in children and adults. Journal of Experimental Psychology: Animal Behavior Processes, 1975, 104, 178-188.

Milewski, A. E., \& Siqueland, E. R. (Brown Univ., Providence, R.I. 02912). Discrimination of color and pattern novelty in one-month human infants. Journal of Experimental Child Psychology, 1975, 19, 122-136.

Millar, S. (Dept. of Exptl. Psychol., S. Parks Rd., Oxford, OX1 3PS, England). Effects of input conditions on intramodel and crossmodal visual and kinesthetic matches by children. Journal of Experimental Child Psychology, 1975, 19, 63-78.

RedD, W. H. (Children's Rsch. Ctr., 51 E. Gerty Dr., Champaign, Ill. 61820), Morris, E. K., \& Martin, J. A. Effects of positive and negative adult-child interactions on children's social preference. Journal of Experimental Child Psychology, 1975, 19, 153-164.

RoHWER, W. D., JR. (Inst. of Human Lrng., Univ. of California, Berkeley, Calif. 94720), KEE, D. W., \& GuY, K. C. Developmental changes in the effects of presentation media on noun-pair learning. Journal of Experimental Child Psychology. 1975, 19. 137-152.

Rohwer. W. D.. JR. (Univ. of California, Inst. of Human 
Lrng.. Berkeley, (alif, 94720), \& MATz, R. D. Improving aural comprehension in white and in black children. Journal of Experimental Child Psychology. 1975, 19. 23-36.

Stein, N. (Syracuse Univ.. 331 Huntington Hall, Syracuse, N.Y. $13210)$, \& Landis, R. Differential reinforcement of low rates performance by impulsive and reflective children. Journal of Experimental Child Psychology, 1975, 19. 37-50.

Stevenson, P. W. (Dept. of Electrical Eng. Sci., Univ. of Essex. Colchester. Essex, England). Responses to speech audiometry and phonemic discrimination patterns in the elderly. Audiologi, 1975, 14, 185-231.

TENNEY, Y. J. (Sch. of Language \& Communication, Hampshire Coll.. Amherst. Mass. 01002). The child's conception of organization and recall. Journal of Experimental Child Psychology, 1975, 19, 100-114.

Thompson, G. B. (Faculty of Ed., Monash Univ., Clayton, Victoria, Australia, 3168). Discrimination of mirror-image shapes by young children. Journal of Experimental Child Psychology, 1975. 19. 165-176.

TraGakis, C. (Univ. of British Columbia, Vancouver 8, Canada). Stimulus interaction and transfer of discrimination in children.

- Journal of Experimental Child Psychology, 1975, 19, 3-22.

Turkewitz. G. (Dept. of Pediat., Albert Einstein Coll. of Med. Yeshiva Univ., Bronx. N.Y. 10461), \& CReighton, S. Changes in lateral differentiation of head posture in the human neonate. Developmental Psychobiology, 1974, 8, 85-89.

\section{PERCEPTUAL AND SENSORY PROCESSES} General

Breitmeyer, B., \& Julesz, B. (Bell Labs., Murray Hill, N.J. 07974). The role of on and off transients in determining the psychophysical spatial frequency response. Vision Research, 1975, 15, 411-415.

Ginsburg, N. (Lakehead Univ.. Thunder Bay, Ont., Canada). $\&$ Courtis, R. The effect of value on perceived numerosity. American Journal of Psychology, 1974, 87, 481-486.

Thomas, E. A. C. (Stanford Univ., Stanford, Calif. 94305), \& Weaver. W. B. Cognitive processing and time perception. Perception \& Psychophysics, 1975, 17, 363-367.

\section{Intersensony Comparisons}

Baron. J. (Univ. of Pennsylvania. Philadelphia. Pa. 19174). \& MCKillop, B. J. Individual differences in speed of phonemic analysis, visual analysis, and reading. Acta Psychologica, 1975, 39, 91-96.

Millar, S. (Dept. of Exptl. Psychol., S. Parks Rd., Oxford OX1 3PS. England). Effects of input conditions on intramodal and crossmodal visual and kinesthetic matches by children. Journal of Experimental Child Psychology, 1975, 19, 63-78.

Peterson, L. R. (Indiana Univ.. Bloomington, Ind. 47401), Holsten. J.. \& SPEVAK, P. Spatial coding of auditory signals. Memory \& Cognition, 1975, 3, 243-246.

ROHWER, W. D., JR. (Inst. of Hum. Lrng.. Univ. of California, Berkeley, Calif. 94720), KeE, D. W., \& GuY, K. C. Developmental changes in the effects of presentation media on noun-pair learning. Journal of Experimental Child Psychology. 1975. 19. 137-152.

Rohwer, W. D.. JR. (Inst. of Hum. Lrng., Univ. of California. Berkeley, Calif. 94720), \& MATz, R. D. Improving aural comprehension in white and in black children. Journal of Experimental Child Psychology, 1975, 19. 23-36.

Schreibman, L. (Claremont's Men's Coll., Claremont, Calif. 91711). Effects of within-stimulus and extra-stimulus prompting on discrimination learning in autistic children. Journal of Applied Behavior Analysis, 1975, 8, 91-112.

Illinsions

Crassini, B. (Univ. of Queensland, St. Lucia, Australia, 4067), d Over, R. Masking, aftereffect, and illusion in visual perception of curvature. Perception \& Psychophysics. $1475,17.411-416$.
Curthoys, I. (Univ. of Sydney, Sydney 2006, Australia). Wenteroth. P.. \& Harris. J. The effects of the motion path and the length of the variable segment in the Poggendorft illusion without parallels. Perception \& Psychophysics, 1975, 17. 358-362.

Lavie, P. (VA Hosp., 3350 La Jolla Village Dr., San Diego, Calif. 92161), Levy, C. M., \& Coolidge, F. L. Ultradian rhythms in the perception of the spiral aftereffect. Physiological Psychology, 1975, 3, 144-146.

Newman, C. V. (Univ. of Birmingham, Birmingham, BI5 2TT, England). \& Newman, B. M. The Ponzo illusion in pictures with and without suggested depth. American Journal of Psychology, 1974, 87, 511-516.

White, K. G. (Colorado Coll., Colorado Springs, Colo. 80903). Orientation effects on contour interaction in the Zöllner illusion. Perception \& Psychophysics, 1975, 17, 387-392.

Worrall, N. (Univ. of London Inst. of Ed., London. England). A test of Gregory's theory of primary constancy scaling. American Journal of Psychology, 1974, 87, 505-511.

\section{Psychophysics}

Chipman, S. F. (Ctr. for Human Performance, Univ. of Michigan, Ann Arbor. Mich. 48104), \& CAREY, S. Anatomy of a stimulus domain: The relation between multidimensional and unidimensional scaling of noise bands. Perception \& Psychophysics, 1975, 17, 417-424.

Kappauf, W. E. (Univ. of Illinois, Champaign, Ill. 61820). Regression effect in judgments to determine equal response contours. Perception \& Psychophysics, 1975, 17, 405-410.

Овоrne, D. J. (Univ. Coll. of Swansea, Swansea. Glam., Wales), \& ClaARKE. M. J. The effect of rating scale parameters on the assessment of vibration intensity. Ergonomics, 1975, 18, 67.79.

WeIss, D. J. (California State Univ., 5151 State University Dr., Los Angeles. Calif. 90032). Quantifying private events: A functional measurement analysis of equisection. Perception \& Psychophysics, 1975, 17, 351-357.

Signal Detection

KAY, E. (Lehigh Univ.. Bethlehem, Pa. 18015), \& Weber, J. Detection in a four-observation two-channel task. Perception \& Psychophysics, 1975, 17, 425-428.

Martin. R. F. (Jamestown Coll., Jamestown, N. Dak. 58401). The theory of signal detectability and implications from functional theories of perception for its application to social perception. Journal of Psychology, 1975, 89, 55-65.

Moskowitz. H. (Inst. of Transportation \& Traffic Eng.. UCLA, Los Angeles, Calif. 90024), \& McGlothlin, W. Effects of marihuana on auditory signal detection. Psychopharmacologia (Berlin), 1974, 40, 137-145.

\section{Vision}

Blank, K., Provine, R. R., \& Enoch, J. M. (Dept. of Ophthalmol.. Univ. of Florida Coll. of Med., Gainesville. Fla. 32610). Shift in the peak of the photopic StilesCrawford function with marked accommodation. Vision Research, 1975, 15, 499-507.

Broerse, J., Over, R. (Univ. of Queensland, St. Lucia, Australia 4067), \& Lovegrove, W. Loss of wavelength selectivity in contour masking and aftereffect following dichoptic adaptation. Perception \& Psychophysics, 1975, 17, 333-336.

Crassini, B. (Univ. of Queensland. St. Lucia. Queensland. Australia 4067), \& Over, R. Masking, aftereffect, and illusion in visual perception of curvature. Perception \& Psychophysics. $1975,17,411-416$

Higgins. K. E. (Div. of Visual Sci.. Pennsylvania Coll. of Optometry, Philadelphia, Pa. 19141). \& Rinalducci. E. J. The spatial Broca-Sulzer and sensitization effects for foveal viewing. Vision Research, 1975, 15, 423-425.

Leibowitz, H. W. (417 Bruce V. Moore Bldg.. Pennsylvania State Univ.. University Park. Pa. 16802), \& Hennessy, R. T. 
The laser optometer and some implications for behavioral research. American Psychologist, 1975, 30, 349-352.

Polley, E. H. (Depts. of Anat. \& Ophthalmol.. Univ. of Illinois Coll. of Med.. Chicago, Ill. 60612). Apple, D. J., \& Bizzell, J. W. The laser as a research tool in visual system investigation. American Psychologist, 1975, 30, 340-348.

von Grünau, M. W. (Univ. of Toronto, Ont., Canada). The "fluttering heart" and spatio-temporal characteristics of color processing- $\mathrm{I}$. Reversibility and the influence of luminance. Vision Research, 1975, 15, 431-436.

von Grünau, M. W. (Univ. of Toronto, Ont., Canada). The "fluttering heart" and spatio-temporal characteristics of color processing-II. Lateral interactions across the chromatic border. Vision Research, 1975, 15, 437-440.

Westendorf. D. H., \& Fox. R. (Vanderbilt Univ., Nashville, Tenn. 37240). Binocular detection of vertical and horizontal line segments. Vision Research, 1975, 15. 471-476.

\section{Spatial Vision}

Chipman, S. F. (Ctr. for Hum. Perf., Univ. of Michigan, Ann Arbor, Mich. 48104), \& CAREY, S. Anatomy of a stimulus domain: The relation between multidimensional and unidimensional scaling of noise bands. Perception \& Psychophysics, 1975, 17, 417-424.

Clark, B. (San Jose State Univ., San Jose, Calif. 95100), \& STewart, J. D. Choice-reaction time to visual motion with varied levels of simultaneous rotary motion. American Journal of Psychology, 1974, 87, 441-448.

Conn, T. E. (Sch. of Optom., Univ. of California, Berkeley, Calif. 94720), \& LASLEY, D. J. Spatial summation of foveal increments and decrements. Vision Research, 1975, 15, 389-399.

Foley, J. M. (Univ. of California. Santa Barbara, Calif. 93106), Applebaum, T. H., \& Richards, W. A. Stereopsis with large disparities: Discrimination and depth magnitude. Vision Research, 1975, 15, 417-421.

Freeman, R. D. (Sch. of Optom., Univ. of California, Berkeley, Calif. 94720). Asymmetries in human accommodation and visual experience. Vision Research, 1975, 15, 483-492.

Griggs, R. A.. \& Restle, F. (Indiana Univ., Bloomington, Ind. 47401). Comparisons of lengths of lines separated horizontally and vertically. Perception \& Psychophysics, 1975, 17, 371-374.

Held, R. (M.I.T., Cambridge, Mass. 02139), Dichgans, J., \& BAUER, J. Characteristics of moving visual scenes influencing spatial orientation. Vision Research, 1975, 15, 357-365.

Kotlyarsky, A. M. (Helmholtz Inst. of Ophthalmol., Moscow, USSR), \& Zhilkin, A. M. A new method for stabilizing the position of retinal images. Vision Research, 1975, 15, 337-339.

Meyer, G. E. (SUNY, 4230 Ridge Lea Rd., Amherst, N.Y. 14226), Lawson, R., \& Cohen, W. The effects of orientationspecific adaptation on the duration of short-term visual storage. Vision Research, 1975, 15, 569-572.

Paris, J., \& Prestrude, A. M. (Virginia Polytech. Inst. \& State Univ.. Blacksburg, Va. 24061). On the mechanisms of the interocular light adaptation effect. Vision Research. 1975, 15. 595-603.

Predebon, G. M., Wenderoth, P. M. (Univ. of Sydney, Sydney, Australia 2006), \& Curthoys, I. S. The effects of instructions and distance on judgments of off-size familiar objects under'natural viewing conditions. American Journal of Psychology, 1974, 87, 425-439.

RAYNER, K. (Ctr. for Devel., Lrng., \& Instruction, Univ. of Rochester, Rochester, N.Y. 14627). The perceptual span and peripheral cues in reading. Cognitive Psychology, 1975, 7, 65-81.

Thompson, G. B. (Faculty of Ed., Monash Univ., Clayton, Victoria. Australia, 3168). Discrimination of mirror-image shapes by young children. Journal of Experimental Child Psychology, 1975, 19, 165-176.

TYleR, C. W. (Bell Tel. Labs., Murray Hill, N.J. 07974). Spatial organization of binocular disparity sensitivity. Vision Research. 1975. 15, 583-590.
W Arren, D. H. (Univ. of California, Riverside, Calif. 92502), \& Platt, B. B. Understanding prism adaptation: An individual differences approach. Perception \& Psychophysics, 1975, 17. 337-345.

WRIGHT, J. C. (Dept. of Electrical Eng., Tech. Inst., Northwestern Univ., Evanston, Ill. 60201), \& KerTEsz, A. E. The role of positional and orientational disparity cues in human fusional response. Vision Research, 1975, 15, 427-430.

\section{Color Vision}

Cohen. J. D. (Mt. Holyoke Coll., South Hadley, Mass. 01075). Temporal independence of the Bezold-Brucke hue shift. Vision Research, 1975, 15, 341-351.

Crassini. B. (Univ. of Queensland, St. Lucia, Queensland, Australia 4067), \& Over, R. Curvature-specific color aftereffects. Perception \& Psychophysics, 1975, 17, 398-404.

Milewski, A. E., \& Siqueland, E. R. (Brown Univ., Providence, R.I. 02912). Discrimination of color and pattern novelty in one-month human infants. Journal of Experimental Child Psychology. 1975, 19. 122-136.

Polizzotto, L. (103 Lexington St., Auburndale, Mass. 02166), \& Peura, R. A. A mathematical approach to explain subjective color perception. Vision Research, 1975, 15, 613-616.

Tannenbaum, P. M. (E. I. Dupont De Nemours \& Co., Exptl. Station, Wilmington. Del. 19898). Spectral shaping and waveguide modes in retinal cones. Vision Research, $1975,15,591-593$.

Valberg, A. (Inst. of Physics, Univ. of Oslo, Oslo 3, Norway). Light adaptation and the saturation of colours. Vision Research, 1975, 15, 401-404.

\section{Eye Movements}

Collewisn, H. (Dept. of Physiol., Faculty of Med., Erasmus Univ., Rotterdam. The Netherlands), van DER MARK, F., \& JANSEN, T. C. Precise recording of human eye movements. Vision Research. 1975, 15, 447-450.

Geiselman, R. E. (Ohio Univ.. Athens, Ohio 45701). Semantic positive forgetting: Another cocktail party problem. Journal of Verbal Learning and Verbal Behavior, 1975, 14, 73-81.

HochberG, J. (Columbia Univ.. New York, N.Y. 10027). On the control of saccades in reading. Vision Research, 1975. 15, 620 .

Holly, F. (Bio-Optics Div., U.S. Army Aeromed. Rsch. Lab. P.O. Box 577. Fort Rucker, Ala. 36360). Saccade presentation of a moving target. Vision Research, 1975, 15, 331-335.

Kopp, C. B. (Dept. of Pediat., UCLA, Los Angeles, Calif. 90024). Sigman. M., Parmelee, A. H., \& Jeffrey, W. E. Neurological organization and visual fixation in infants at 40 weeks conceptional age. Developmental Psychobiology, 1975, 8 . 165-170.

Monty, R. A. (Behav. Rsch. Directorate, U.S. Army Human Eng. Lab., Aberdeen Proving Ground, Md. 21005). An advanced eye-movement measuring and recording system. American Psychologist, 1975, 30, 331-335.

Prablanc, C. (Laboratoire de Neuropsychologie Experimentale, Unite U 94 INSERM, 69500 Bron, France), \& JeANNERod, M. Corrective saccades: Dependence on retinal reafferent signals. Vision Research, 1975, 15, 465-469.

Russo, J. E. (Univ. of California, San Diego, P.O. Box 109, La Jolla, Calif. 92037), \& Rosen, L. D. An eye fixation analysis of multialternative choice. Memory \& Cognition, 1975, 3, $267-276$

Verbaten, M. N. (Psychol. Lab., State Univ. of Utrecht, Utrecht, The Netherlands), Beaujon, J. N. R., \& Suouw, W. EEG alpha rhythm. ocular activity and basal skin resistance. Acta Psychologica, 1975, 39, 153-160.

Young, L. R. (Dept. of Aeronautics \& Astronautics, M.I.T., Cambridge, Mass. 02139), \& Sheena, D. Eye-movement measurement techniques. American Psychologist, 1975, 30. 315-330. 


\section{Audition}

Auditory Discrimination

Andreassi, J. L. (Baruch Coll., CUNY, New York, N.Y. 10010), De Simone, J. J., Friend, M. A., \& Grota, P. A. Hemispheric amplitude asymmetries in the auditory evoked potential with monaural and binaural stimulation. Physiological Psychology, 1975, 3, 169-171.

BENCH, J. (Royal Berkshire Hosp., Reading RG1 5AP, England), LANGFord, C., \& Wilson, I. Some effects of prestimulus activity and length of prestimulus observation on judgments of infants' auditory behaviour. Audiology, 1975, 14, 164-172.

Colquhoun, W. P. (MRC Applied Psychol. Unit, Lab. of Exptl. Psychol., Univ. of Sussex, Brighton, Sussex, England), \& EDwards, R. S. Interaction of noise with alcohol on a task of sustained attention. Ergonomics, 1975, 18, 81-87.

Deutsch, D. (Ctr. for Hum. Info. Processing. Univ. of California, San Diego, P.O. Box 109, La Jolla, Calif. 92037). Facilitation by repetition in recognition memory for tonal pitch. Memory \& Cognition, 1975, 3, 263-266.

Jerger, S. (Div. of Audiol., Methodist Hosp., Tex. Med. Ctr., Mail Station 009. Houston, Tex. 77025), \& Jerger, J. Extraand intra-axial brain stem auditory disorders. Audiology, 1975, $14,92-11 \%$.

Kallman, H. J., \& Corballis, M. C. (McGill Univ., Montreal, P.Q., Canada H3C 3G1). Ear asymmetry in reaction time to musical sounds. Perception \& Psychophysics, 1975, 17, 368-370.

Mencher, G. T. (Speech \& Hrg. Clin. 5919 South St., c/o I.W.K. Hosp. for Children, Halifax, N.S., Canada), Kushner, M., \& McCulloch, B. White noise as a pretest sensitizer for neonatal hearing screening. Audiology, 1975, 14, 152-163.

Olsen, W. (Mayo Clin., Rochester, Minn. 55901), \& Carhart, R. Head diffraction effects on ear-level hearing aids. Audiology, 1975, 14, 244-258.

Roeser, R. J. (Callier Ctr. for Communication Disorders \& Hlth. Sci. Ctr., Univ. of Texas, 1966 Inwood Rd., Dallas, Tex. 75235), \& Glorig, A. Pure tone audiometry in noise with auraldomes. Audiology, 1975, 14, 144-151.

Sohmer, H. (Dept. of Physiol., Hebrew Univ., Hadassah Med. Sch., P.O. Box 1172, Jerusalem, Israel), \& PratT, H. Electrocochleography during noise-induced temporary threshold shifts. Audiology, 1975, 14, 130-134.

Stark, E. W. (Dept. of Speech \& Hrg. Sci., 322 Illini Hall, Univ. of Illinois. Urbana-Champaign, Ill. 61820), \& Burton, T. E. Noise-excluding enclosure for audiometry. Audiology, $1975,14,232-237$.

Zerlin, S. (Otolaryngol. Section, Univ. of Chicago, 950 E. 59th St., Chicago, Ill. 60637), \& Naunton, R. F. Physical and auditory specifications of third-octave clicks. Audiology, $1975,14,135-143$.

Speech Discrimination

Routh, D. A. (Univ. of Bristol, 8-10 Berkeley Sq., Bristol, BS8 $1 \mathrm{HH}$, England), \& Lifschutz, A. J. An asymmetrical effect of similarity in the attenuation of stimulus suffix interference. Journal of Verbal Learning and Verbal Behavior. 1975, 14. 95-104.

Stevenson. P. W. (Dept. of Electrical Eng. Sci., Univ. of Essex. Colchester, Essex, England). Responses to speech audiometry and phonemic discrimination patterns in the elderly. Audiology, 1975, 14, 185-231.

WoOd. C. C. (Div. of Neuropsychiat., Walter Reed Army Inst. of Rsch.. Washington, D.C. 20012), \& DAY, R. S. Failure of selective attention to phonetic segments in consonant-vowel syllables. Perception \& Psychophysics, 1975. 17, $346-350$.

\section{Other Senses}

Oborne, D. J. (Univ. Coll. of Swansea, Swansea, Glam., Wales), \& CLARKE, M. J. The effect of rating scale parameters on the assessment of vibration intensity. Ergonomics, 1975, 18. $0,-79$.
Shaver, L. G. (Phys. Ed. Dept., SUNY, Brockport, N.Y. 14420). Cross transfer effects of conditioning and deconditioning on muscular strength. Ergonomics, 1975, 18, 9-16.

\section{Skin Senses}

Griffiths, I. D. (Atkins Rsch. \& Devel., Ashley Rd., Epson, Surrey, England;, \& McIntyre, D. A. The effect of mental effort on subjective assessments of warmth. Ergonomics, 1975, 18, 29-33.

Kappauf, W. E. (Univ. of Illinois, Champaign, Ill. 61802). Regression effect in judgments to determine equal response contours. Perception \& Psychophysics, 1975, 17, 405-410.

Milosevic, S. (Inst. of Psychol., Belgrade, Yugoslavia). Changes in detection measures and skin resistance during an auditory vigilance task. Ergonomics, 1975, 18, 1-8.

Sherrick, C. E. (Princeton Univ., Princeton, N.J. 08540). The art of tactile communication. American Psychologist, $1975,30,353-360$.

\section{PERFORMANCE}

Adams, R. G. (Hlth. Dept., Vale Dr., Clin, Vale Dr., Barnet, Herts., England). Pre-sleep ingestion of two hypnotic drugs and subsequent performance. Psychopharmacologia (Berlin), 1974, 40, 185-190.

Aitken, P. P., \& Hutt, C. (Univ. of Keele, Keele, Staffs. ST5 5BG, England). The effects of stimulus incongruity upon children's attention, choice, and expressed preference. Journal of Experimental Child Psychology, 1975, 19, 79-87.

SmeEts, P. M. (Univ, of Leiden, Rijnsburgerweg, Leiden, The Netherlands), \& Striefel, S. The effects of different reinforcement conditions on the test performance of multihandicapped deaf children. Journal of Applied Behavior Analysis, 1975, 8, 83-89.

\section{Psychomotor Tasks}

Dureman, I. (Univ. of Uppsala, Uppsala, Sweden), \& Norrman, B. Clinical and experimental comparison of diazepam. chlorazepate and placebo. Psychopharmacologia (Berlin), 1975, 40, 279-284.

Fowler, S. C. (Univ. of Mississippi, University, Miss. 38677), \& Notterman, J. M. An observed short-term motor memory effect for isometric force emission. Perception \& Psychophysics, 1975, 17, 393-397.

Hicks, R. E. (SUNY, 1400 Washington Ave., Albany, N.Y. 12222). Provenzano, F. J., \& Rybstein, E. D. Generalized and lateralized effects of concurrent verbal rehearsal upon performance of sequential movements of the fingers by the left and right hands. Acta Psychologica, 1975, 39. 119-130.

Mannell, R. C. (Faculty of Physiol. \& Hith. Ed., Univ. of Windsor, Windsor. Ont., Canada N9B 3P4), \& DuthIE, J. H. Habit lag: When "automatization" is dysfunctional. Journal of Psychology, 1975, 89, 73-80.

Seymour, P. H. K. (The Univ., Dundee, Scotland), \& Sanford, A. J. Interaction of concurrent generative and expressive activity in production of typewritten lists. Acta Psychologica. 1975, 39, 141-152.

Thies, A. P., \& Chance, J. (Univ. of Missouri, Columbia, Mo. 65201). Potential losses versus potential gains as determinants of behavior. Journal of Psychology. 1975, 89, 81-88.

Turkewitz, G. (Dept. of Pediat.. Albert Einstein Coll. of Med., Yeshiva Univ.. Bronx, N.Y. 10461), \& CREIGHron. S. Changes in lateral differentiation of head posture in the human neonate. Developmental Psychobiology, 1974, 8. 85-89.

\section{Réaction Time}

Andreassi, J. L. (Baruch Coll., CUNY, 155 E. 24th St., New York. N.Y. 10010), \& GRECo, J. R. Effects of bisensory stimulation on reaction time and the evoked cortical potential. Physiological Psychology, 1975, 3, 189-194.

Blake, J. (York Unniv., 4700 Keele St., Downsview, 463. Ont., Canada). \& Beilin, H. The development of same and different 
judgments. Journal of Experimental Child Psychology, 1975, 19. 177-194.

Clark, B. (San Jose State Univ., San Jose, Calif. 95100), \& STEwarT, J. D. Choice-reaction time to visual motion with varied levels of simultaneous rotary motion. American Journal of Psychology, 1974, 87, 441-448.

Coles, M. G. H. (Univ. of Illinois, Champaign, Ill. 61820), Porges, S. W., \& Duncan-Johnson, C. C. Sex differences in performance and associated cardiac activity during a reaction time task. Physiological Psychology, 1975, 3, 141-143.

Cooper, L. A. (Univ. of California, San Diego, La Jolla, Calif. 92037). Mental rotation of random two-dimensional shapes. Cognitive Psychology, 1975, 7, 20-43.

Geller. E. S. (Virginia Polytech. Inst. \& State Univ., Blacksburg, Va. 24061), Tuso, M. A., \& Wellington, C. J. The outcome of a coactor's prediction as a determinant of choice reaction time. Bulletin of the Psychonomic Society, 1975, 5, 303-305.

Gilhooly, K. J. (King's Coll., Aberdeen Univ., Old Aberdeen, AB9 2UB, Scotland). Latencies and confidence in n-value concept learning. Acta Psychologica, 1975. 39, 105-118.

Glencross. D. J. (Flinders Univ. of South Australia, Bedford Park. South Australia 5042). The effects of changes in task conditions on the temporal organization of a repetitive speed skill. Ergonomics, 1975, 18, 17-28.

Hock, H. S. (Florida Atlantic Univ., Boca Raton, Fla. 33432), Gordon. G. P., \& Gold, L. Individual differences in the verbal coding of familiar visual stimuli. Memory \& Cognition, 1975, 3, 257-262.

Kallman, H. J., \& Corballis, M. C. (McGill Univ., Montreal, P.Q.. Canada H3C 3G1). Ear asymmetry in reaction time to musical sounds. Perception \& Psychophysics, 1975, 17, 368-370.

Link, S. W. (McMaster Univ., Hamilton, Ont., Canada). The relative judgment theory of two choice response time. Journal of Mathematical Psychology, 1975, 12. 114-135.

\section{Attention}

Fryklund, I. (Univ. of Illinois at Chicago Circle, Box 4348, Chicago. Ill. 60680). Effects of cued-set spatial arrangement and target-background similarity in the partial-report paradigm. Perception \& Psychophysics, 1975, 17, 375-386.

Gatchel, R. J. (Univ. of Texas, Arlington, Tex. 76019). Effects of interstimulus interval length on short- and long-term habituation of autonomic components of the orienting response. Physiological Psychology, 1975, 3, 133-136.

Harris, L. J. (Michigan State Univ., East Lansing, Mich. 48824). Spatial direction and grammatical form of instructions affect the solution of spatial problems. Memory \& Cognition, 1975, 3. 329-334.

Howard, J. H., JR. (The Catholic Univ., Washington, D.C. 20017). The attentional demands of negation in a memoryscanning task. Memory \& Cognition, 1975, 3, 319-324.

Milosevic, S. (Inst. of Psychol., Belgrade, Yugoslavia). Changes in detection measures and skin resistance during an auditory vigilance task. Ergonomics, 1975, 18, 1-8.

\section{Information Processing}

Johnson, N. F. (Ohio State Univ., Columbus, Ohio 43210). On the function of letters in word identification: Some data and a preliminary model. Journal of Verbal Learning and Verbal Behavior, 1975, 14, 17-29.

Norman, D. A. (Univ. of California, San Diego, La Jolla 92037), \& BoвRow, D. G. On data-limited and resource-limited processes. Cognitive Psychology, 1975, 7, 44-64.

Pennington, F. M. (Univ. of Alabama, University, Ala. 35486), \& Luszcz, M. A. Some functional properties of iconic storage in retarded and nonretarded subjects. Memory \& Cognition, 1975, 3, 295-301.

Russo, J. E. (Univ. of California, San Diego, P.O. Box 109, La Jolla, Calif. 92037), \& Rosen, L. D. An eye fixation analysis of multialternative choice. Memory \& Cognition, 1975, $3,267-276$.
Vunderink, R. A. F. (Inst. for Perception TNO, Soesterberg Kampweg 5, Postbus 23, The Netherlands), \& SANDERs, A. F. A wide-screen projection system for human performance studies American Psychologist, 1975, 30, 336-339.

\section{HUMAN LEARNING}

Andersson, K. (Psychol. Labs., Univ. of Stockholm, Box 6706. Stockholm S-11385, Sweden). Effects of cigarette smoking on learning and retention. Psychopharmacologia (Berlin), 1975, 41. $1-5$.

Gillin, J. C. (Lab. of Clin. Psychopharmacol., SMR, IRP, NIMH, St. Elizabeths Hosp., Washington, D.C. 20032), Fram, D. H., WyatT, R. J., Henkin, R. I., \& SNYDER, F. L-histidine: Failure to affect the sleep-waking cycle in man. Psychopharmacologia (Berlin), 1975, 40. 305-311.

Lavie, P. (VA Hosp., 3350 La Jolla Village Dr., San Diego, Calif. 92161), Levy, C. M., \& Coolidge, F. L. Ultradian rhythms in the perception of the spiral aftereffect. Physiological Psychology, 1975, 3, 144-146.

LeVere, T. E. (North Carolina State Univ., Raleigh, N.C. 27607), Morlock, G. W., \& HaRT, F. D. Waking performance decrements following minimal sleep disruption: The effects of habituation during sleep. Physiological Psychology, 1975, 3, $147-154$

\section{Conditioning}

Lubow, R. E. (Tel-Aviv Univ., Ramat-Aviv, Israel), Alek, M., \& ARZY, J. Behavioral decrement following stimulus preexposure: Effects of number of preexposures, presence of a second stimulus, and interstimulus interval in children and adults. Journal of Experimental Psychology: Animal Behavior Processes, 1975, 104, 178-188.

Prokasy, W. F. (Univ. of Utah, Salt Lake City, Utah 84112), Williams, W. C., \& ClaRK, C. G. Skin conductance response conditioning with CS intensities equal to and greater than UCS intensity. Memory \& Cognition, 1975, 3, 277-281.

Shaver, L. G. (Phys. Ed. Dept., SUNY, Brockport, N.Y. 14420). Cross transfer effects of conditioning and deconditioning on muscular strength. Ergonomics, 1975, 18, 9-16.

Wilson, G. T. (Psychol. Clin., Rutgers Univ., New Brunswick, N.J. 08903), Leaf, R. C., \& Nathan, P. E. The aversive control of excessive alcohol consumption by chronic alcoholics in the laboratory setting. Journal of Applied Behavior Analysis, $1975,8,13-26$.

\section{Discrimination Learning}

JACoBy, L. L. (Iowa State Univ., Ames, Iowa 50010). Physical features vs meaning: A difference in decay. Memory \& Cognition, 1975, 3, 247-251.

Schreibman, L. (Claremont's Men's Coll., Claremont, Calif. 91711). Effects of within-stimulus and extra-stimulus prompting on discrimination learning in autistic children. Journal of Applied Behavior Analysis, 1975, 8, 91-112.

Switzky, H. N. (Northern Wisconsin Colony \& Trng. Sch., Chippewa Falls, Wis. 54729). The effects of cue distinctiveness on the learning of intradimensional shifts by retarded persons. American Journal of Psychology, 1974, 87, 399-407.

\section{Verbal Learning}

Clinton, L. (Univ. of Illinois, Champaign, Ill. 61820), \& BoyCE, K. D. Rule-governed imitative verbal behavior as a function of modeling procedures. Journal of Experimental Child Psychology, 1975, 19, 115-124.

Conlin, D., \& Paivio, A. (Univ. of Western Ontario, London 72, Ont., Canada). The associative learning of the deaf: The effects of word imagery and signability. Memory \& Cognition, 1975, 3, 335-340.

Galbrith, R. C. (Northwestern Univ., Evanston, Ill. 60201). Encoding variability and the concreteness effect in pairedassociate learning. Memory \& Cognition, 1975, 3, 282-286. 
Nelson. D. L. (Univ. of South Florida. Tampa, Fla. 36620), Borden. R. C.. \& Wheeler, J. W. Sensory features and the reduction of imaginal interference. Memony \& Cognition. 1975. 3. $239-242$.

RAYNER, K. (Ctr. for Devel., Lrng., \& Instruction, Univ. of Rochester, N.Y. 14627). The perceptual span and peripheral cues in reading. Cognitive Psychology, 1975, 7, 65-81.

Rohwer. W. D., JR. (Inst. of Hum. Lrng., Univ. of California. Berkeley, Calif. 94720), KeE, D. W., \& GuY, K. C. Developmental changes in the effects of presentation media on noun-pair learning. Journal of Experimental Child Psychology, 1975, 19, 137-152.

UNDERWOOD, B. J. (Northwestern Univ., Evanston, Ill. 60201), \& REICHARDT, C. S. Contingent associations and the doublefunction. verbal discrimination task. Memory \& Cognition. 1975, 3, 311-314.

\section{Reinforcement}

Armelius, B.-A. (Univ. of Umea, Umea, Sweden), \& Armelius, $\mathrm{K}$. The use of redundancy in multiple-cue judgments: Data from a suppressor-variable task. American Journal of Psychologv, 1974, 87, 385-392.

Eagle, M. N. (York Univ., 4700 Keele St., Downsview, Ont., Canada M3J 1P3), \& Mulliken, S. The role of affective ratings in intentional and incidental learning. American Journal of Psychology, 1974, 87, 409-423.

Goetz, E. M. (Dept. of Hum. Devel., Univ. of Kansas, Lawrence, Kans. 66045). Holmberg, M. C., \& LeBlanc, J. M. Differential reinforcement of other behavior and noncontingent reinforcement as control procedures during the modification of a preschooler's compliance. Journal of Applied Behavior Analy'sis, 1975, 8, 77-82.

Lindell. M. K., \& Stewart, T. R. (Inst. of Behav. Sci., Univ. of Colorado, Boulder. Colo. 80302). The effects of redundancy in multiple-cue probability learning. American Journal of Psychology, 1974, 87, 393-398.

SMEETS, P. M. (Univ, of Leiden, Rijnsburgerweg, Leiden, The Netherlands), \& Striefel, S. The effects of different reinforcement conditions on the test performance of multihandicapped deaf children. Journal of Applied Behavior Analysis, 1975, 8, 83-89.

Stein, N. (Syracuse Univ.. 331 Huntington Hall, Syracuse, N.Y. 13210), \& LANDIs, R. Differential reinforcement of low rates performance by impulsive and reflective children. Journal of Experimental Child Psychology, 1975, 19, 37-50.

Thies, A. P., \& Chance, J. (Univ. of Missouri, Columbia, Mo. 65201). Potential losses versus potential gains as determinants of behavior. Journal of Psychology, 1975, 89, 81-88.

Thornton, J. W. (Angelo State Univ., San Angelo, Tex. 76901), \& Powell, G. D. Immunization to and alleviation of learned helplessness in man. American Journal of Psychology, 1974, 87. $351-367$.

\section{HUMAN MEMORY}

Andersson, K. (Psychol. Labs., Univ. of Stockholm, Box 6706, Stockholm, S-11385, Sweden). Effects of cigarette smoking on learning and retention. Psychopharmacologia (Berlin), 1975, 41, $1-5$.

Barron, R. W. (Univ. of Guelph, Guelph, Ont., Canada N1G NIG 2W1). Locus of the effect of a distinguishing feature in a memory search task. Memory \& Cognition, 1975, 3, 302-310.

Brewer, W. F. (Univ. of Illinois, Champaign, Ill. 61820), \& Lichtenstein, E. H. Recall of logical and pragmatic implications in sentences with dichotomous and continuous antonyms. Memory \& Cognition, 1975, 3, 315-318.

Deutsch, D. (Ctr. for Hum. Info. Processing, Univ. of California, San Diego, P.O. Box 109, La Jolla, Calif. 92037). Facilitation by repetition in recognition memory for tonal pitch. Memory \& Cognition, 1975, 3, 263-266.
Elmes. D. G. (Washington \& Lee Univ., Lexington, Va. 24450), $\&$ BJork, R. A. The interaction of encoding and rehearsal processes in the recall of repeated and nonrepeated items. Journal of Verbal Learning and Verbal Behavior, 1975, 14, $30-42$.

Foss, D. J. (Univ. of Texas, Austin, Tex. 78712), \& Harwood, D. A. Memory for sentences: Implications for human associative memory. Journal of Verbal Learning and Verbal Behavior, 1975, 14, 1-16.

Geiselman, R. E. (Ohio Univ., Athens, Ohio 45701). Semantic positive forgetting: Another cocktail party problem. Journal of Verbal Learning and Verbal Behavior, 1975, 14, 73-81.

Healy, A. F. (Yale Univ., New Haven, Conn. 06520), \& JoNEs, C. Can subjects maintain a constant criterion in a memory task? Memory \& Cognition, 1975, 3, 233-238.

Hintzman, D. L. (Univ. of Oregon, Eugene, Oreg. 97403), Summers, J. J., \& Block, R. A. What causes the spacing effect? Some effects of repetition, duration, and spacing on memory for pictures. Memory \& Cognition, 1975, 3, 287-294.

Huang, K. L. (Univ. of Georgia, Athens, Ga. 30602), \& PAYNE, R. B. Individual and sex differences in reminiscence. Memory \& Cognition, 1975, 3, 252-256.

JACOBY, L. L. (Iowa State Univ., Ames, Iowa 50010). Physical features vs meaning: A difference in decay. Memory \& Cognition, 1975, 3. 247-251.

Kellas, G. (Univ. of Kansas, Lawrence, Kans. 66045), McCauley, C., \& McFarland, C. E., JR. Developmental aspects of storage and retrieval. Journal of Experimental Child Psychology, 1975, 19, 51-62.

Loftus, G. R. (Univ. of Washington. Seattle, Wash. 98195), \& Patterson, K. K. Components of short-term proactive interference. Journal of Verbal Learning and Verbal Behavior. 1975, 14, 105-121.

Mannell, R. C. (Faculty of Phys. \& Hlth Ed., Univ. of Windsor, Windsor, Ont., Canada N9B 3P4), \& Duthie, J. H. Habit lag: When "automatization" is dysfunctional. Journal of Psychology, 1975, 89, 73-80.

Moeser, S. D. (Memorial Univ. of Newfoundland, St. John's. Ntld., Canada). Iconic factors and language word order. Journal of Verbal Learning and Verbal Behavior, 1975, 14. 43-55.

Монs, R. C. (Stanford Univ., Stanford, Calif. 94305), \& Wescourt, K. T. Processing multiple recognition probes in short- and long-term memory. Bulletin of the Psychonomic Society, 1975, 5, 319-322.

READ, J. D. (Univ. of Lethbridge, Lethbridge, Alta., Canada T1K 3M4), \& Peterson. R. H. Individual differences in the ease of imagining the faces of others. Bulletin of the Psychonomic Society. 1975, 5, 347-349.

Routh, D. A. (Univ. of Bristol. 8-10 Berkeley Sq.. Bristol. BS8 $1 \mathrm{HH}$. England), \& Lifschutz. A. J. An asymmetrical effect of similarity in the attenuation of stimulus suffix interference. Journal of Verbal Learning and Verbal Behavior. 1975. 14, 95-104.

Santa, J. L. (Rutgers Univ., Douglass Coll., New Brunswick, N.J. 08903), Ruskin, A. B., Snuttjer, D.. \& Baker, L. Retrieval in cued recall. Memory \& Cognition. 1975, 3, 341-348.

Schwartz, R. M. (Rio Hondo Coll.. Whittier, Calif. 90608). Organization and recognition accuracy: The effect of context on blocked presentation. Bulletin of the Psychonomic Society. 1975, 5, 329-330.

\section{Long-Term Memory}

Appelman, I. B.. \& Atrinson, R. C. (Stanford Univ.. Stanford, Calif. 94305). Search of list structures stored in long-term memory. Journal of Verbal Learning and Verbal Behavior, 1975, 14, 82-88.

Bellezza, F. S. (Ohio Univ.. Athens. Ohio 47501), \& Schirmann, N. J. Response dependence in simultaneously learned A-B. 
A-C lists. Journal of Verbal Learning and Verbal Behavior, 1975, 14. 89-94.

Glidden. L. M. (Box 89, Teachers Coll., Columbia Univ., New York. N.Y. 10027), \& Scotт, K. G. Recognition memory retention interval and information load. Journal of Experimental Child Psychology, 1975, 19, 195-208.

Howard, J. H., JR. (Catholic Univ., Washington, D.C. 20017). The attentional demands of negation in a memory-scanning task. Memon \& Cognition, 1975, 3, 319-324.

Overcast, T. D., Murphy, M. D., Smiley, S. S., \& Brown, A. L. (Children's Rsch. Ctr., 51 Gerty Dri., Champaign, 11l. 61820). The effects of instructions on recall and recognition of categorized lists by the elderly. Bulletin of the Psychonomic Society. 1975, 5, 339-341.

Tenney. Y. J. (Sch. of Language \& Communication, Hampshire Coll.. Amherst. Mass. 01002). The child's conception of organization and recall. Journal of Experimental Child Psichology, 1975. 19. 100-114.

van Dam. G. (Psychol. Lab.. Univ. of Utrecht, Varkenmarkt 2, Utrecht. The Netherlands), PeEck, J., Brinkerink, M., \& Gorter. U. The isolation effect in free recall and recognition. American Journal of Psychology, 1974, 87, 497-504.

\section{Short-Term Memory}

Adams, R. G. (Hlth. Dept., Vale Dr. Clinic, Vale Dr., Barnet. Herts., England). Pre-sleep ingestion of two hypnotic drugs and subsequent performance. Psychopharmacologia (Berlin). 1974, 40, 185-190.

Fowler, S. C. (Univ. of Mississippi, University, Miss. 38677), \& Notterman, J. M. An observed short-term motor memory effect for isometric force emission. Perception \& Psychophysics, 1975, 17. 393-397.

Fryklund, I. (Univ. of Illinois at Chicago Circle, Box 4348, Chicago. III. 60680). Effects of cued-set spatial arrangement and target-background similarity in the partial-report paradigm. Perception \& Psychophysics, 1975, 17, 375-386.

Pennington, F. M. (Univ. of Alabama, University, Ala. 35486). \& Luszcz, M. A. Some functional properties of iconic storage in retarded and nonretarded subjects. Memory \& Cognition, 1975, 3, 295-301.

\section{Transfer}

EARHARD, B. (Dalhousie Univ., Halifax, N.S., Canada), EARHARD, M.. \& Fried, C. A. Retroactive inhibition and retrieval independence. American Journal of Psychology, 1974. 87, 449-461.

LaPorte, R., \& Voss, J. F. (Univ. of Pittsburgh, Pittsburgh, $\mathrm{Pa} .15260)$. Nonspecitic transfer as a function of number of lists acquired and criterion of learning. American Journal of Psychology, 1974, 87, 463-474.

LaPorte, R., Voss, J. F. (Univ. of Pittsburgh, Pittsburgh, Pa. 15260), \& Bisanz, G. Nonspecific transfer with and without test trials on the first list. American Journal of Psychology, 1974, 87, 475-479.

Petrich, J. A. (Univ. of Pittsburgh, Pittsburgh, Pa. 15260). Retroactive inhibition under a multiple-choice procedure. American Journal of Psychology, 1974, 87, 335-349.

Reynolds, J. H. (Colgate Univ., Hamilton, N.Y. 13346), \& Goldstein, J. A. The effects of category membership on memory scanning for words. American Journal of Psychology, 1974, 87, 487-495.

Tragakis, C. (Univ. of British Columbia, Vancouver 8, B.C., Canada). Stimulus interaction and transfer of discrimination in children. Journal of Experimental Child Psychology, 1975. 19, 3-22.

\section{HUMAN THINKING}

Cooper, L. A. (Univ. of California, San Diego, La Jolla, Calif. 92037). Mental rotation of random two-dimensional shapes. Cognitive Psychology, 1975, 7, 20-43.
Harris, L. J. (Michigan State Univ., East Lansing, Mich. 48824). Spatial direction and grammatical form of instructions affect the solution of spatial problems. Memory \& Cognition, 1975. 3. 329-334.

Kochen, M. (MHRI. Univ. of Michigan, Ann Arbor, Mich. 48104). \& BADRE, A. N. Questions and shifts of representation in problem solving. American Journal of Psychology, 1974, 87, 369-383.

YARemko, R. M. (San Diego State Univ.. San Diego, Calif. 92182). \& BUTLER, M. C. Imaginal experience and attenuation of the galvanic skin response to shock. Bulletin of the Psychonomic Society. 1975, 5, 317-318.

\section{Verbal Processes}

Clark, H. H. (Stanford Univ., Stanford, Calif. 94305), \& LuCY, P. Understanding what is meant from what is said: A study in conversationally conveyed requests. Journal of Verbal Learning and Verbal Behavior, 1975, 14, 56-72.

Носк, H. S. (Florida Atlantic Univ., Boca Raton, Fla. 33432), Gordon, G. P.. \& Gold, L. Individual differences in the verbal coding of familiar visual stimuli. Memory \& Cognition, 1975, 3, 257-262.

Lindsley, J. R. (12 Oliver Rd., Watertown, Mass. 02172). Producing simple utterances: How far ahead do we plan? Cognitive Psychology. 1975, 7, 1-19.

Moeser, S. D. (Memorial Univ. of Newfoundland, St. John's, Ntld.. Canada). Iconic factors and language word order. Journal of Verbal Learning and Verbal Behavior, 1975, 14, 43-55.

\section{Concepts}

Adams, E. W. (Univ. of California, Berkeley, Calif. 94720), \& FAGOT, R. F. On the theory of biased bisection operations and their inverses. Journal of Mathematical Psychology, 1975, 12, 35-52.

Gilhooly, K. J. (King's Coll., Aberdeen Univ., Old Aberdeen, AB9 2UB. Scotland). Latencies and confidence in n-value concept learning. Acta Psychologica, 1975, 39, 105-118.

Indow, T. (Keio Univ., Minato-ku, Tokyo, Japan), Koвayashi, M.. \& Dewa, S. Concept identification with natural material. Acta Psychologica, 1975, 39, 131-139.

Krantz, D. H. (Univ. of Michigan, Ann Arbor. Mich. 48104), \& TVERSKY. A. Similarity of rectangles: An analysis of subjective dimensions. Journal of Mathematical Psychology, 1975, 12, 4-34.

Ling, R. F. (Univ. of Chicago, Chicago, Ill. 60637). An exact probability distribution on the connectivity of random graphs. Journal of Mathematical Psychology, 1975, 12, 90-98.

Link, S. W. (McMaster Univ., Hamilton, Ont., Canada). The relative judgment theory of two choice response time. Journal of Mathematical Psychology, 1975, 12, 114-135.

Richter, M. K. (Dept. of Economics, Univ. of Minnesota, Minneapolis, Minn. 55455). Rational choice and polynomial measurement models. Journal of Mathematical Psychology, 1975, 12, 99-113.

SHePARD, R. N. (Stanford Univ., Stanford, Calif. 94305), Kilpatric, D. W., \& Cunningham, J. P. The internal representation of numbers. Cognitive Psychology, 1975, 7, 82-138.

Thomas, E. A. C. (Stanford Univ., Stanford, Calif. 94305), \& WeAVER, W. B. Cognitive processing and time perception. Perception \& Psychophysics, 1975, 17, 363-367.

Tolor, A. (Inst. for Hum. Devel., Fairfield Univ., Fairfield, Conn. 06430), Cramer, M., D'Amico, D., \& O'Marra, M. M. The effects of self-concept, trust, and imagined positive or negative self-disclosures on psychological space. Journal of Psychology, 1975, 89, 9-24.

\section{SOCIAL PROCESSES}

'Geller, E. S. (Virginia Polytech. Inst. \& State Univ., 
Blacksburg, Va. 24061). Tuso, M. A., \& Wellington, C. J. The outcome of a coactor's prediction as a determinant of choice reaction time. Bulletin of the Psychonomic Society, 1975, 5, 303-305.

Goetz, E. M. (Dept. of Hum. Devel., Univ. of Kansas, Lawrence, Kans. 66045), Holmberg, M. C., \& LeBlanc, J. M. Differential reinforcement of other behavior and noncontingent reinforcement as control procedures during the moditication of a preschooler's compliance. Journal of A pplied Behavior Analysis, 1975, 8, 77-82.

Harkins, S., Becker, L. A. (Univ. of Missouri, Columbia, Mo. 65201), \& STONneR, D. Extraversion-introversion and the effects of favorability and set size on impression formation. Bulletin of the Psychonomic Society, 1975, 5, 300-302.

Hendrick, C. (Kent State Univ., Kent, Ohio 44242), Franz, C. M., \& Hoving, K. L. How do children form impressions of persons? They average. Memory \& Cognition, 1975, 3, 325-328.

McGovern, L. P., Ditzian, J. L., \& Taylor, S. P. (Kent State Univ., Kent, Ohio 44242). Sex and perceptions of dependency in a helping situation. Bulletin of the Psychonomic Society, 1975, 5, 336-338.

READ, J. D. (Univ. of Lethbridge, Lethbridge, Alta., Canada T1K 3M4), \& PEterson, R. H. Individual differences in the ease of imagining the faces of others. Bulletin of the Psychonomic Society, 1975, 5, 347-349.

Redd, W. H. (Children's Rsch. Ctr., 51 E. Gerty Dr., Champaign, Ill. 61820), Morris, E. K., \& Martin, J. A Effects of positive and negative adult-child interactions on children's social preference. Journal of Experimental Child Psychology, 1975, 19, 153-164.

\section{ANIMAL LEARNING \& BEHAVIOR}

\section{DEVELOPMENT}

Groswald, D. E. (Dept. of Aerosp. Eng. Sci., Univ. of Colorado, Boulder, Colo. 80302), \& Lutrges, M. W. Developmental and genetic variables in mouse startle response habituation. Developmental Psychobiology, 1974, 8, 41-48.

\section{Early Development}

Brown, R. T. (Univ. of North Carolina, Davie Hall, Wilmington, N.C. 28401). Discrepancy from rearing conditions affects chicks' behavior in a novel situation. Developmental Psychobiology. 1975, 8, 187-191.

Caul, W. F. (Vanderbilt Univ., Nashville, Tenn. 37240), Freeman. B. J., \& Buchanan, D. C. Effects of differential rearing condition on heart rate conditioning and response suppression. Developmental Psychobiology, 1974, 8, 63-68.

LEE, M. H. S. (The Univ., Hull, HV6 7RX, England), \& Williams. D. I. Long term changes in nest condition and pup grouping following handling of rat litters. Developmental Psychobiology, 1974, 8, 91-95.

Martin, J. T. (Dept. of Anim. Sci., Univ. of Minnesota, St. Paul. Minn. 55108), \& Schutz, F. Arousal and temporal factors in imprinting in mallards. Developmental Psychobiology, 1974, 8, 69-78.

Olton, D. S. (Johns Hopkins Univ., Baltimore, Md. 21218), Johnson. C. T., \& HowARD, E. Impairment of conditioned active avoidance in adult rats given corticosterone in infancy. Developmental Psychobiology, 1974, 8, 55-61.

Oswalt, G. L. (Úniv. of Nebraska, Omaha, Nebr. 68105), \& Косн. M. D. Temperature, handling, micturition, and the survival of early weaned rats. Animal Learning \& Behavior, 1975. 3, 123-124.

Oswalt, G. L. (Univ. of Nebraska, Omaha, Nebr. 68101), \& Meier, G. W. Olfactory, thermal, and tactual influences on infantile ultrasonic vocalization in rats. Developmental Psychobiology. 1975, 8, 129-135.

Singh, P. J. (Dept. of Psychiat., Albert Einstein Coll. of Med., 111 E. 210st St., Bronx, N.Y. 10467), \& ТовасH, E. Olfactory bulbectomy and nursing behavior in rats pups (Wistar DAB). Developmental Psychobiology, 1975, 8, 151-164.

Wyly, M. V., Denenberg, V. H. (Dept. of Biobehav. Sci., Univ. of Connecticut, Storrs, Conn. 06268), DE SAntis, D., Burns, J. K., \& Zarrow, M. X. Handling rabbits in infancy: In search of a critical period. Developmental Psychobiology, 1975, 8, 179-186.

\section{Developmental Changes}

Adler, M. W. (Dept. of Pharmacol., Temple Univ. Sch. of Med., Philadelphia, Pa. 19140), Mauron, C., SAmanin, R., \& VALZELLI, L. Morphine analgesia in grouped and isolated rats. Psychopharmacologia (Berlin), 1975, 41, 11-14.

Blozovski, D. (Laboratoire de Psychophysiologie, Universite Paris VI, Cedex 05, Paris, France), Bachevalier, J. Effect of atropine on behavioral arousal in the developing rat. Developmental Psychobiology, 1975, 8, 97-102.

Brown, R. T. (Univ. of North Carolina, Wilmington, N.C. 28401). Following and visual imprinting in ducklings across a wide age range. Developmental Psychobiology, 1974, 8, 27-33.

Flandera, V. (Inst. of Physiol., Czechoslovak Acad. of Sci., Prague, Czechoslovakia), \& Novakova, V. Effect of mother on the development of aggressive behavior in rats. Developmental Psychobiology, 1974, 8, 49-54.

Goldman, L., \& Swanson, H. H. (Dept. of Anat., Univ. of Birmingham, Birmingham, B15 2TJ, England). Developmental changes in pre-adult behavior in confined colonies of golden hamsters. Developmental Psychobiology, 1975, 8, 137-150.

Goyens, J. (Lab. of Exptl. Psychol., Univ. of Brussels, 1050 Brussels, Belgium), \& NoIrot, E. Effects of cohabitation with females on aggressive behavior between male mice. Developmental Psychobiology, 1974, 8, 79-84.

Syme, L. A. (Univ. of Western Australia, Nedlands, W.A. 6009 , Australia). Influence of age and sex on the behavior of rats deprived of the rearing response. Developmental Psychobiology, $1974,8,35-39$.

Thompson, R. W. (Western Washington State Coll., Bellingham, Wash. 98225), \& Lippman, L. G. The effect of age and postweaning and adult handling habituation on activity and exploration in the rat. Bulletin of the Psychonomic Society, 1975, 5, 285-288.

\section{MOTIVATION AND EMOTION}

Daniel, W., \& King, G. D. (Auburn Univ., Auburn, Ala. 36830). The consequences of restricted water accessibility on schedule-induced polydipsia. Bulletin of the Psychonomic Society, 1975, 5, 297-299.

Ison, J. R. (Univ. of Rochester, Rochester, N.Y. 14627), \& KRAUTER, E. E. Acoustic startle reflexes in the rat during consummatory behavior. Journal of Comparative and Physiological Psychology, 1975, 89, 39-49.

O’Brien, T. J., \& Dunlap, W. P. (Tulane Univ., New 
Orleans. La. 70118). Tonic immobility in the blue crab (Callinectes sapidus, Rathbun): Its relation to threat of predation. Journal of Comparative and Physiological Psychology, 1975, 89, 86-94.

Syme, L. A. (Univ. of Western Australia, Nedlands, W.A. 6009, Australia). Influence of age and sex on the behavior of rats deprived of the rearing response. Developmental Psychobiology, 1974. 8. 35-39.

Wyly. M. V., Denenberg, C. H. (Dept. of Biobehav. Sci., Univ. of Connecticut. Storrs. Conn. 06268), De Santis, D., Burns, J. K., \& ZarRow, M. X. Handling rabbits in infancy: In search of a critical period. Developmental Psychobiology, 1975, 8, 179-186.

\section{Activity and Exploratory Behavior}

Blozovski, D. (Laboratoire de Psychophysiologie, Universite Paris VI. Cedex 05, Paris, France), \& Bachevalier, J. Effect of atropine on behavioral arousal in the developing rat. Developmental Psychobiology, 1975, 8, 97-102.

Groswald, D. E. (Dept. of Aerosp. Eng. Sci., Univ. of Colorado, Boulder, Colo. 80302), \& Lutrges, M. W. Developmental and genetic variables in mouse startle response habituation. Developmental Psychobiology, 1974, 8. 41-48.

Houser, V. P. (Psychotropic Drug Lab., VA Hosp., Perry Point, Md. 21902). Effects of chronic administration and withdrawal of d-amphetamine upon daily activity levels of squirrel monkeys. Bulletin of the Psychonomic Society, 1975, 5, 313-314.

Thompson, R. W. (Western Washington State Coll., Bellingham, Wash. 98225), \& Lippman, L. G. The effect of age and postweaning and adult handling habituation on activity and exploration in the rat. Bulletin of the Psychonomic Society, $1975,5,285-288$.

\section{Hunger and Thirst}

Barrett, J. E. (Univ. of Maryland, College Park, Md. 20741). \& WEINBERG, E. S. Effects of chlordiazepoxide on schedule-induced water and alcohol consumption in the squirrel monkey. Psychopharmacologia (Berlin). 1975, 40. 319-328.

Kemble, E. D. (Univ. of Minnesota, Morris. Minn. 56267), \& NAGEL. J. A. Decreased sniffing behavior in rats following septal lesions. Bulletin of the Psychonomic Society, 1975, 5, 309-310.

Kulkosky, P. J. (Univ. of Washington, Seattle, Wash. 98195), Moe, K. E., Woods, S. C., \& Riley, A. L. Effect of ventromedial hypothalamic lesions on schedule-induced polydipsia. Physiological Psychology, 1975, 3, 172-174.

MABRY, P. D. (Princeton Univ., Princeton, N.J. 08540), \& CAMpBell, B. A. Food-deprivation-induced behavioral arousal: Mediation by hypothalamus and amygdala. Journal of Comparative and Physiological Psychology, 1975, 89, 19-38.

MineKA, S. (Charter \& Johnson Sts., Univ. of Wisconsin, Madison, Wis. 53706). Some new perspectives on conditioned hunger. Journal of Experimental Psychology: Animal Behavior Processes, 1975, 104, 134-148.

Rowland, N. (Psychobiol. Program, 454 Crawford Hall, Univ. of Pittsburgh, Pittsburgh, Pa. 15260). Feeding patterns in rats in restricted access schedules: Palatability, bulk, and other determinants of intake. Bulletin of the Psychonomic Society, 1975, 5, 306-308.

\section{Sexual and Maternal Behavior}

Adkins, E. K. (SUNY, Cortland, N.Y. 13045). Hormonal basis of sexual differentiation in the Japanese quail. Journal of Comparative and Physiological Psychology, 1975, 89, 61-71.

Brown. R. T. (Univ. of North Carolina, Wilmington, N.C. 28401). Following and visual imprinting in ducklings across a wide age range. Developmental Psychobiology, 1974, 8, $27-34$.
Caul, W. F. (Vanderbilt Univ., Nashville. Tenn. 37240), Freeman, B. J.. \& Buchanan, D. C. Effects of differential rearing condition on heart rate conditioning and response suppression. Developmental Psychobiology, 1974. 8. 63-68.

HandWerker, M. J., \& Fishbein, W. (City Coll. of CUNY, New York, N.Y. 10031). Neural excitability after paradoxical sleep deprivation: A replication and further examination. Physiological Psychology, 1975, 3, 137-140.

Krischik, V. A., \& Weber, P. G. (Biol. Sci.. SUNY, Oswego, N.Y. 13126). Induced parental care in male convict cichlid fish. Developmental Psychobiology, 1974, 8, 1-11.

LeE, M. H. S. (The Univ., Hull, England), \& Williams, D. I. Long term changes in nest condition and pup grouping following handling of rat litters. Developmental Psychobiology, 1974, 8, 91-95.

Oswalt, G. L. (Univ. of Nebraska, Omaha, Nebr. 68105), \& $\mathrm{Koch}, \mathrm{M}$. D. Temperature, handling, micturition, and the survival of early weaned rats. Animal Learning \& Behavior, 1975, 3, 123-124.

Rodriguez-Sierra, J. F. (Inst. of Anim. Behav., Rutgers Univ., 101 Warren St., Newark, N.J. 07102), CROWlEY, W. R., \& Komisaruk, B. R. Vaginal stimulation in rats induces prolonged lordosis responsiveness and sexual receptivity. Journal of Comparative and Physiological Psychology, 1975, 89, 79-85.

SinGH, P. J. (Dept. of Psychiat., Albert Einstein Coll. of Med.. 111 E. 210th St., Bronx, N.Y. 10467), \& Товасн, E. Olfactory bulbectomy and nursing behavior in rat pups (Wistar DAB). Developmental Psychobiology, 1975, 8, 151-164.

\section{SOCIAL AND ABNORMAL BEHAVIOR}

Adler, M. W. (Dept. of Pharmacol., Temple Univ. Sch. of Med., Philadelphia, Pa. 19140), Bendotti, C., Ghezzi, D., Samanin, R., \& Valzelli, L. Dependence to morphine in differentially housed rats. Psychopharmacologia (Berlin), 1975. 41, 15-18.

Flandera, V. (Inst. of Physiol., Czechoslovak Acad. of Sci.. Prague, Czechoslovakia), \& Novakova, V. Effect of mother on the development of aggressive behavior in rats. Developmental Psychobiology, 1974, 8, 49-54.

Goyens, J. (Lab. of Exptl. Psychol.. Univ. of Brussels, 1050 Brussels. Belgium), \& NoIrot, E. Effects of cohabitation with females on aggressive behavior between male mice. Developmental Psychobiology, 1974, 8, 79-84.

Latané, B. (404C W. 17th Ave., Columbus, Ohio 43210), \& SteEle, C. The persistence of social attraction in socially deprived and satiated rats. Animal Learning \& Behavior, 1975, 3, 131-134.

Meliska, J. A., Meliska, C. J. (Monmouth Coll., Monmouth, III. 61462), Hoyenga, K. T., Hoyenga, K. B.. \& WARD, E. F. Approach tendency and threat display as related to social status of Siamese fighting fish, Betta splendens. Animal Learning \& Behavior, 1975, 3, 135-139.

\section{SENSORY FUNCTIONS}

Goldman, L., \& Swanson, H. H. (Dept. of Anat., Univ. of Birmingham, Birmingham, B15 2TJ. England). Developmental changes in pre-adult behavior in confined colonies of golden hamsters. Developmental Psychobiology, 1975, 8, 137-150.

Oswalt, G. L. (Univ. of Nebraska, Omaha, Nebr. 68101), \& MeIER, G. W. Olfactory, thermal, and tactual influences on infantile ultrasonic vocalization in rats. Developmental Psychobiology, 1975, 8, 129-135.

\section{Vision}

Easter, S. S., JR. (Dept. of Zool., Univ. of Michigan, Ann Arbor, Mich. 48104). The time course of saccadic eye movements in gold fish. Vision Research, 1975, 15, 405-409.

Guld, C. (Inst. of Neurophysiol., Univ. of Copenhagen, Copenhagen, Denmark), \& Bertulis, A. Contact lenses for animals used in vision research. Vision Research, 1975. 15, $441-442$ 
Hood, D. C. (Columbia Univ., New York, N.Y. 10027), \& Hock, P. A. Light adaptation of the receptors: Increment threshold functions for the frog's rods and cones. Vision Research, 1975, 15, 545-553.

JACoBs, G. H. (Univ. of California, Santa Barbara, Calif. 93106), \& BIRCH, D. Increment-threshold functions for different rodent species. Vision Research, 1975, 15, 375-378.

Loop, M. S., \& Berkley, M. A. (Florida State Univ., Tallahassee, Fla. 32306). Temporal modulation sensitivity of the cat-I. Vision Research, 1975, 15, 555-561.

Martin, G. R. (Univ. of Sussex, Lab. of Exptl. Psychol., Sussex, England), Gordon, I. E., \& CADLE, D. R. Electroretinographically determined spectral sensitivity in the tawny owl (Strix aluco). Journal of Comparative and Physiological Psychology, 1975, 89, 72-78.

Matsumoto, N. (Dept. of Biophys. Eng., Faculty of Eng. Sci., Osaka Univ., Toyonaka, Osaka, Japan). Responses of the amacrine cell to optic nerve stimulation in the frog retina. Vision Research, 1975, 15, 509-514.

Padmos, P. (Inst. for Perception TNO, Kampweg 5, Soesterberg, The Netherlands), \& Norren, D. V. Cone systems interaction in single neurons of the lateral geniculate nucleus of the macaque. Vision Research, 1975, 15, 617-619.

Premack, D. (Univ. of California, Santa Barbara, Calif. 93106). Putting a face together. Science, 1975, 188, 228-236.

Roffe, T. (502 NW 12th St., Corvallis, Oreg. 97330). Spectral perception in Octopus: A behavioral study. Vision Research, 1975, 15, 353-356.

SARMiento, R. F. (SUNY, Brockport, N.Y. 14420). The stereoacuity of macaque monkey. Vision Research, 1975, 15, 493-498.

SRinivasan, M. V. (Dept. of Ophthalmol. \& Vis. Sci., Yale Univ., 333 Cedar St., New Haven, Conn. 06510), \& Bernard, G. D. The effect of motion on visual acuity of the compound eye: A theoretical analysis. Vision Research, 1975, 15, 515-525.

\section{ANIMAL LEARNING AND RETENTION} Conditioning

Frey, P. W. (Northwestern Univ., Cresap Lab. of Neurosci. \& Behav., 2021 Sheridan Rd., Evanston, Ill. 60201), \& Gavin, W. Overnight incubation of a partially conditioned eyeblink response in rabbits. Animal Learning \& Behavior, 1975, 3, 114-118.

Killeen, P. (Arizona State Univ., Tempe, Ariz. 85281). On the temporal control of behavior. Psychological Review, $1975,82,89-115$.

Martin, J. T. (Dept. of Anim. Sci., Univ. of Minnesota, St. Paul, Minn. 55108), \& Schutz, F. Arousal and temporal factors in imprinting in mallards. Developmental Psychobiology, 1974, 8, 69-78.

\section{Classical Conditioning}

Herendeen, D. L., \& Shapiro, M. M. (Emory Univ., Atlanta, 30322). Extinction and food-reinforced inhibition of conditioned salivation in dogs. Animal Learning \&. Behavior, 1975, 3, 103-106.

Pearce, J. M. (Lab. of Exptl. Psychol., Univ. of Sussex, Brighton, England, BN1 9QG), \& Dickinson, A. Pavlovian counterconditioning: Changing the suppressive properties of shock by association with food. Journal of Experimental Psychology: Animal Behavior Processes, 1975, 104, 170-177.

Terry, W. S., \& Wagner, A. R. (Yale Univ., New Haven, Conn. 06520). Short-term memory for "surprising" vs "expected" unconditioned stimuli in Pavlovian conditioning. Journal of Experimental Psychology: Animal Behavior Processes, $1975,104,122-133$.

Testa, T. J. (Univ. of Pennsylvania Dept. of Psychiat., c/o VA Hosp., University \& Woodland Aves., Philadelphia,
Pa. 19104). Effects of similarity of location and temporal intensity pattern of conditioned and unconditioned stimuli on the acquisition of conditioned suppression in rats. Journal of Experimental Psychology: Animal Behavior Processes, 1975, 104, 114-121.

\section{Operant Conditioning}

Czerwinski, A. S. (McMaster Univ., Hamilton, Ont. L8S 4K1, Canada), \& Rodwan, A. S. Effect of errorcontingent time-out on spaced responding in rats. Bulletin of the Psychonomic Society, 1975, 5, 342-344.

Feldman, J. M. (Dept. of Behav. Sci., Coll. of Optometry, SUNY, 131 E. 23rd St., 7th floor, New York, N.Y. 10010). Blocking as a function of added cue intensity. Animal Learning \& Behavior, 1975, 3, 98-102.

Holt, G. L. (Eastern Illinois Univ., Charleston, Ill. 61920). Correction procedures in extinction of matching behavior. Bulletin of the Psychonomic Society, 1975, 5, 209-212.

Lewis, M. J., Margules, D. L., \& WARD, O. B., JR. (Villanova Univ., Villanova, Pa. 19085). Opioid-reinforced operant behavior: Selective suppression by alpha-methylpara-tyrosine. Journal of Comparative and Physiological Psychology, 1975, 88, 519-527.

MineKa, S. (Univ. of Wisconsin, Charter \& Johnson Sts., Madison, Wis. 53706). Some new perspectives on conditioned hunger. Journal of Experimental Psychology: Animal Behavior Processes, 1975, 104, 134-148.

Wasserman, E. A. (Univ. of Iowa, Iowa City, Iowa 52242), Hunter, N. B., Gutowski, K. A., \& Bader, S. A. Autoshaping chicks with heat reinforcement: The role of stimulus-reinforcer and response-reinforcer relations. Journal of Experimental Psychology: Animal Behavior Processes, 1975, 104, 158-169.

Zentall, T. R. (Univ. of Pittsburgh, Pittsburgh, Pa. 15260), \& HogAN, D. E. Key pecking in pigeons produced by pairing keylight with inaccessible grain. Journal of the Experimental Analysis of Behavior, 1975, 23, 199-206.

\section{Conditioned Aversions}

Best, M. R. (Furman Univ., Greenville, S.C. 29613). Conditioned and latent inhibition in taste-aversion learning: Clarifying the role of learned safety. Journal of Experimental Psychology, 1975, 104, 97-113.

Bond, N. (Sch. of Behav. Sci., Macquarie Univ., North Ryde, N.S.W. 2113, Australia), \& Di Giusro, E. Amount of solution drunk is a factor in the establishment of taste aversion. Animal Learning \& Behavior, 1975, 3, 81-84.

Fernandez, B., \& Ternes, J. W. (Caribbean Primate Rsch. Ctr., Univ. of Puerto Rico, Sabana Seca, Puerto Rico 00794). Conditioned aversion to morphine with lithium chloride in morphine-dependent rats. Bulletin of the Psychonomic Society, 1975, 5, 331-332.

Frumkin, K. (For reprints write Peter M. Milner, McGill Univ., P.O. Box 6070, Montreal 101, P.Q., Canada). Effects of deprivation schedule on the maintenance of a preoperative salt aversion by adrenalectomized rats. Physiological Psychology, 1975. 3, 101-106.

Gadusek, F. J., \& Kalat, J. W. (Duke Univ., Durham, N.C. 27706). Effects of scopolamine on retention of taste-aversion learning in rats. Physiological Psychology, 1975, 3, 130-132.

Miller, C. R. (Georgia Coll., Milledgeville, Ga. 31061), Elkins, R. L., Fraser, J., Peacock, L. J., \& Hobbs, S. H. Taste aversion and passive avoidance in rats with hippocampal lesions. Physiological Psychology, 1975, 3, 123-126.

Rosellini, R. A. (Univ. of Pennsylvania, 3815 Walnut St., Philadelphia, Pa. 19174), \& Seligman, M. E. P. Frustration and learned helplessness. Journal of Experimental Psychology: Animal Behavior Processes, 1975, 104, 149-157. 


\section{Discrimination Learning}

Belingham, W. P. (Australian National Univ., Canberra, A.C.T Australia 20(0). Storilien, L. H., \& Stebulis, R. J. Discrimination learning in the T-maze based on the secondary reinforcing effects of shock termination. Bulletin of the Psichonomic Society. 1975, 5, 327-328.

Leith. C. R. (Northern Michigan Univ., Marquette. Mich. 49855). \& MaKı, W. S., JR. Attention shifts during matching-tosample performance in pigeons. Animal Learning \& Behavior. $1975,3,85-89$.

Richardson. W. K. (Georgia State Univ., University Plaza, Atlanta, Ga. 30303). \& Evans, M. S. The effect of localizing the stimulus at the response key on generalization along the hue dimension in the pigeon. Animal Learning \& Behuvior. 1975, 3, 119-122.

Worsham, R. W. (Sch. of Theor. \& Appl. Sci., Ramapo Coll., Mahwah, N.J. 07430). Temporal discrimination factors in the delayed matching-to-sample task in monkeys. Animal Learming \& Behavior, 1975, 3, 93-97.

\section{Maze and Runway Behavior}

Bellingham, W. P. (Australian National Univ., Canberra, A.C.T Australia 2600), Storlien, L. H., \& Stebulis, R. J. Discrimination learning in the $\mathrm{T}$-maze based on the secondary reinforcing effects of shock termination. Bulletin of the Psychonomic Society, 1975, 5, 327-328.

Capaldi, E. J. (Purdue Univ.. West Lafayette, Ind. 47907), \& FreEse, M. R. Alley section effects of magnitude of partial reward after extensive acquisition training. Bulletin of the Psychonomic Society, 1975, 5, 294-296.

Slavin, R. S., \& Tallarico, R. B. (Univ. of Miami, P.O. Box 8185. Coral Gables, Fla. 33124). Successive acquisition and extinction in a runway with the domestic Muscovy duck (Cairina moschata). Animal Leaming \& Behavior, 1975, 3, 90-92.

Webster, M., \& Webster. D. B. (Kresge Hrg. Rsch. Lab. of the South. Louisiana State Univ.. Med. Ctr.. New Orleans. La. 70119). Maze running in kangaroo rats with sensory deprivations. Physiological Psychology, 1975, 3, 195-200.

\section{Avoidance and Punishment}

Downey. D. J, (Univ. of Arizona, Tucson, Ariz. 85721). State-dependent learning with centrally and noncentrally active drugs. Bulletin of the Psychonomic Society, 1975, 5, 281-284.

\section{Aroidance}

Bolles, R. C. (Univ, of Washington, Seattle, Wash. 98105), \& NELSON, K. The role of intertrial interval in the learning of two simple avoidance tasks. Animal Learning \& Behavior. 1975. 3. 157-160.

Dickinson. A. (Lab. of Exptl. Psychol., Univ. of Sussex, Brighton, England, BN1 9QG), \& MoRRIs, R. G. M. Conditioned acceleration and free-operant wheel-turn avoidance following septal lesions in rats. Physiological Psychology, 1975, 3, 107-112.

Mellgren, R. L. (Univ, of Oklahoma, Norman, Okla. 73069), Hunsicker, J. P., \& Dyck, D. G. Conditions of preexposure and passive avoidance behavior in rats. Animal Learning \& Behatior, 1975, 3, 147-151.

Olton, D. S. (Johns Hopkins Univ., Baltimore. Md. 21218), Johnson, C. T., \& HowARD, E. Impairment of conditioned active avoidance in adult rats given corticosterone in infancy. Developmental Psychobiology, 1974, 8, 55-62.
Zerbolio, D. J., Jr. (Univ. of Missouri, St. Louis, Mo. 63121). \& WICKSTRA, L. L. The effect of power (US intensity $x$ US duration) on shuttlebox avoidance acquisition in goldfish. Bulletin of the Psychonomic Society, 1975, 5. 345-347.

\section{Punishment}

Ernst, A. J. (Washington State Univ.. Pullman, Wash. 99163), \& YEE, R. W. A developmental analysis of the relationship between response strength and punishment. Animal Learning \& Behavior, 1975, 3, 107-113.

Ном. H. L., JR. (Southwest Missouri State Univ., Springfield, Mo. 65802), \& BABB, H. Self-punitive responding in rats with goal shock and color change. Animal Leaming \& Behavior, 1975. 3. $152-156$

King, G. D. (Auburn Univ., Auburn, Ala. 36830), \& Sides, J. P. Punishment of schedule-induced wheel running. Bulletin of the' Psychonomic Society, 1975, 5, 323-324.

McKearney, J. W. (Worcester Fdtn. for Exptl. Biol., Shrewsbury, Mass. 01545), \& BarRetT, J. E. Punished behavior: Increases in responding after $d$-amphetamine. Psychopharmacologia (Berlin), 1975, 41, 23-26.

\section{Reinforcement}

Bersh, P. J. (Temple Univ., Philadelphia, Pa. 19122), \& MiLLER, $K$. The intluence of shock during response prevention upon resistance to extinction of an avoidance response. Animal Learning \& Behavior, 1975, 3, 140-142.

Capaldi, E. J. (Purdue Univ., West Lafayette, Ind. 47907), \& FreEse, M. R. Alley section effects of magnitude of partial reward after extensive acquisition training. Bulletin of the Psychonomic Society, 1975, 5, 294-296.

Davison, C. (Univ. of South Carolina, Columibia, S.C. 29208), Lowther. W. R., \& Allen, J. D. Effect of septal lesions on behavioral contrast. Physiological Psychology, 1975, 3, 179-182.

Schedules of Reinforcement

Czerwinski, A. S. (McMaster Univ., Hamilton, Ont. L8S 4K1, Canada), \& Rodwan, A. S. Effect of error-contingent time-out on spaced responding in rats. Bulletin of the Psychonomic Society, 1975, 5. 342-344.

Daniel, W., \& King, G. D. (Auburn Univ.. Auburn. Ala. 36830). The consequences of restricted water accessibility on schedule-induced polydipsia. Bulletin of the Psychonomic Society, 1975, 5, 297-299.

King, G. D. (Auburn Univ., Auburn, Ala. 36830), \& Sides, J. P. Punishment of schedule-induced wheel running. Bulletin of the Psychonomic Society, 1975, 5, 323-324.

Scobie, S. R. (SUNY, Binghamton, N.Y. 13901), \& Gold, D. C. Differential reinforcement of low rates in goldtish. Animal Leaming \& Behavior, 1975, 3. 143-146.

\section{Retention}

Kamit, A. C. (Univ. of Massachusetts, Amherst, Mass. 01002), \& MAULdin, J. E. Intraproblem retention during learning-set acquisition in bluejays (Cyanocitta cristata). Animal Learning \& Behavior, 1975. 3, 125.130.

Terry, W. S., \& Wagner, A. R. (Yale Univ., New Haven, Conn. 06520). Short-term memory for "surprising" versus "expected" unconditioned stimuli in Pavlovian conditioning. Journal of Experimental Psychology: Animal Behavior Processes. 1975, 104. 122-133. 


\section{PHYSIOLOGICAL PSYCHOLOGY}

\section{BRAIN FUNCTIONS}

Beaumont, G. (Univ. Coll., Cardiff, Wales), \& Dimond, S. Interhemispheric transfer of figural information in right- and non-right-handed subjects. Acta Psychologica, 1975, 39, 97-104.

HIC ks, R. E. (SUNY, 1400 Washington Ave., Albany, N.Y. 12222). Intrahemispheric response competition between vocal and unimanual performance in normal adult human males. Journal of Comparative and Physiological Psychology, 1975, 89, 50-60.

Hicks, R. E. (SUNY, 1400 Washington Ave., Albany, N.Y. 12222), Provenzano, F. J., \& Rybstein, E. D. Generalized and lateralized effects of concurrent verbal rehearsal upon performance of sequential movements of the fingers by the left and right hands. Acta Psychologica, 1975, 39, 119-130.

\section{Lesions}

Hilger, W. N., JR., \& Rowe, F. A. (Illinois Inst. of Tech., Chicago, Ill. 60616). Olfactory bulb ablation: Effects on handling reactivity, open-field behavior, and agonistic behavior in male and female hamsters. Physiological Psychology, 1975, 3, 162-168.

Jerger, S. (Div. of Audiol., Methodist Hosp., Texas Med. Ctr., Mail Station 009, Houston, Tex. 77025), \& JERGER, J. Extra- and intra-axial brain stem auditory disorders. Audiology, 1975, 14, 93-117.

Jerussi, T. P., \& Glick, S. D. (Dept. of Pharmacol. Mt. Sinai Sch. of Med., New York, N.Y. 10029). Apomorphine-induced rotation in normal rats and interaction with unilateral caudate lesions. Psychopharmacologia (Berlin), 1975, 40, 329-334.

Kulkosky, P. J. (Univ. of Washington, Seattle, Wash. 98195), Moe, K. E., Woods, S. C., \& Riley, A. L. Effect of ventromedial hypothalamic lesions on schedule-induced polydipsia. Physiological Psychology, 1975, 3, 172-174.

Singh, P. J. (Dept. of Psychiat., Albert Einstein Coll. of Med., 111 E. 210th St., Bonx, N.Y. 10467), \& Товасн, E. Olfactory bulbectomy and nursing behavior in rat pups (Wistar DAB). Developmental Psychobiology, 1975, 8, 151-164.

Limbic System

Davison, C. (Univ. of South Carolina, Columbia, S.C. 29208), Lowther, W. R., \& Allen, J. D. Effect of septal lesions on behavioral contrast. Physiological Psychology, 1975, 3, 179-182.

Dickinson, A. (Lab. of Exptl. Psychol., Univ. of Sussex, Brighton, England BN1 9QG), \& Morris, R. G. M. Conditioned acceleration and free-operant wheel-turn avoidance following septal lesions in rats. Physiological Psychology, 1975, 3, 107-112.

Donovick, P. J. (SUNY, Binghamton, N.Y. 13901), BURRIGHT, R. G., \& Bentsen, E. O. Presurgical dietary history and the behavior of control and septal lesioned rats. Developmental Psychobiology, 1974, 8, 13-25.

Kemble, E. D. (Univ. of Minnesota, Morris, Minn. 56267), \& NAGEL, J. A. Decreased sniffing behavior in rats following septal lesions. Bulletin of the Psychonomic Society, 1975, 5, 309-310.

Mabry, P. D. (Princeton Univ., Princeton, N.J. 08540), \& CAmpbell, B. A. Food-deprivation-induced behavioral arousal: Mediation by hypothalamus and amygdala. Journal of Comparative and Physiological Psychology, 1975, 89, 19-38.

Miller, C. R. (Georgia Coll., Milledgeville, Ga. 31061), Elkins, R. L., Fraser, J., Peacock, L. J., \& Hobbs, S. H. Taste aversion and passive avoidance in rats with hippocampal lesions. Physiological Psychology, 1975, 3, 123-126.
Ross, J. F., Grossman, L., \& Grossman, S. P. (Univ. of Chicago, 5484 S. University Ave., Chicago, Ill. 60637). Some behavioral effects of transecting ventral or dorsal fiber connections of the septum in the rat. Journal of Comparative and Physiological Psychology, 1975, 89, 5-18.

\section{Stimulation}

Berntson, G. G. (Lab. of Comparative \& Physiol. Psychol., Ohio State Univ., 1314 Kinnear Rd., Columbus, Ohio 43212), \& Beattie, M. S. Functional differentiation within hypothalamic behavioral systems in the cat. Physiological Psychology, 1975, 3, 183-188.

Handwerker, M. J., \& Fishbein, W. (City Coll. of CUNY, New York, N.Y. 10031). Neural excitability after paradoxical sleep deprivation: A replication and further examination. Physiological Psychology, 1975, 3, 137-140.

Lamprecht, F., Ebert, M. H. (Lab. of Clin. Sci., Room 45239, Bldg. 10, NIMH, Bethesda, Md. 20014), TUREK, I., \& Kopin, I. J. Serum dopamine-beta-hydroxylase in depressed patients and the effect of electroconvulsive shock treatment. Psychopharmacologia (Berlin), 1974, 40, 241-248.

Pinel, J. P. J. (Univ. of British Columbia, Vancouver, B.C., V65 1W5, Canada), Mucha, R. F., \& Phillips, A. G. Spontaneous seizures generated in rats by kindling: A preliminary report. Physiological Psychology, 1975, 3 127-129.

\section{Electrical Activity}

Andreassi, J. L. (Baruch Coll., CUNY, New York, N.Y. 10010), De Simone, J. J., Friend, M. A., \& Grota, P. A. Hemispheric amplitude asymmetries in the auditory evoked potential with monaural and binaural stimulation. Physiological Psychology, 1975, 3, 169-171.

Andreassi, J. L. (Baruch Coll., CUNY, 155 E. 24th St., New York, N.Y. 10010), \& GRECo, J. R. Effects of bisensory stimulation on reaction time and the evoked cortical potential. Physiological Psychology, 1975, 3, 189-194.

Berkley, M. A. (Florida State Univ., Tallahassee, Fla. 32306), Loop, M. S., \& Evinger, C. Temporal modulation sensitivity of the cat-II. Evoked potential estimates. Vision Research, $1975,15,563-568$.

Delgado, J. M. R. (Departmento de Ciencias Fisiologicas, Facultad de Medicina Universidad Autonoma, Herederos de Navas, 1, Madrid-34, Spain), Lipponen, V., Weiss, G. Del Pozo, F., Monteagudo, J. L., \& McMahon, R. Two-way transdermal communication with the brain. American Psychologist, 1975, 30, 265-273.

Donchin, E. (Univ. of Illinois, Champaign, Ill. 61820), \& Heffley, E. Minicomputers in the signal-averaging laboratory. American Psychologist, 1975, 30, 299-312.

Munson, J. B. (Depts. of Neurosci. \& Physiol., Coll. of Med., Univ. of Florida, Gainesville, Fla. 32610), VAN Hartesveldt, C. J., \& Spray, D. C. Graded, unitary and eye movement potentials in lateral geniculate nucleus following reticular stimulation. Vision Research, 1975, 15, 443-446.

Roemer, R. A. (Eastern Pennsylvania Psychiat. Inst., Henry \& Abbotsford, Philadelphia, Pa. 19129). Some interactive computer applications in a physiological psychology laboratory. American Psychologist, 1975, 30, 295-298.

Rouse, L. (Biophysics Lab., California State Univ., Fresno, Calif. 93740), Peterson, J., \& Shapiro, G. EEG alpha entrainment reaction within the biofeedback setting and some possible effects on epilepsy. Physiological Psychology, 1975, 3, 113-122.

Verbaten, M. N. (Psychol. Lab., State Univ. of Utrecht, Utrecht, The Netherlands), Beaujon, J. N. R., \& S Jouw, W. EEG alpha rhythm, ocular activity and basal skin resistance. Acta Psychologica, 1975, 39. 153-160. 


\section{PHYSIOLOGICAL EFFECTS}

Adkins. E. K. (SUNY. Cortland. N.Y. 13045). Hormonal basis of sexual differentiation in the Japanese quail. Joumal of Comparative and Physiological Psychology, 1975. 89. 61-71.

Frumkin, K. (For reprints write Peter M. Milner. McGill Univ., P.O. Box 6070. Montreal 101, P.Q.. Canada). Effects of deprivation schedule on the maintenance of a preoperative salt aversion by adrenalectomized rats. Physiological Psychology, 1975, 3, 101-106.

Ho. A. K. S. (Lab. of Neurochem. \& Neuropharmacol., Wayne State Univ.. Coll. of Pharmacy \& Allied Hlth. Professions, Detroit, Mich. 48202), Tsai, C. S., Chen, R. C. A., Begleiter, H., \& Kissin, B. Experimental studies on alcoholism I. Increased in alcohol preference by 5.6-dihydroxytryptamine and brain acetylcholine. Psychopharmacologia (Berlin), 1974. 40, 101-107.

Silverstone, T. (Psychiat. Unit., German Hosp., Dalston E8, England), \& SChUYLER. D. The effect of cyproheptadine on hunger. calorie intake and body weight in man. Psychopharmacologia (Berlin), 1975, 40. 335-340.

Uphouse, L. L. (Yale Univ., New Haven, Conn. 06520), \& Bonner, J. Preliminary evidence for the effects of environmental complexity on hybridization of rat brain RNA to rat unique DNA. Developmental Psychobiology, $1975,8,171-178$.

\section{Drug Effects}

Adams, R. G. (Hlth Dept., Vale Dr. Clin., Vale Dr., Barnet, Herts., England). Pre-sleep ingestion of two hypnotic drugs and subsequent performance. Psychopharmacologia (Berlin). 1974, 40, 185-190.

Adrer, M. W. (Dept. of Pharmacol., Temple Univ. Sch. of Med., Philadelphia, Pa. 19140), Bendotti, C.. Ghezzi, D. Samanin, R., \& Valzelli, L. Dependence to morphine in differentially housed rats. Psychopharmacologia (Berlin). 1975, 41. 15-18.

Adler. M. W. (Dept. of Pharmacol.. Temple Univ. Sch. of Med.. Philadelphia. Pa. 19140), Mauron. C., Samanin, R., \& VALZELLI. L. Morphine analgesia in grouped and isolated rats. Psychopharmacologia (Berlin). 1975, 41, 11-14.

Andersson, K. (Psychol. Labs.. Univ. of Stockholm, Box 6706. Stockholm S-11385. Sweden). Effects of cigarette smoking on learning and retention. Psichopharmacologia (Berlin), 1975, 41. 1-5.

Barrett. J. E. (Univ. of Maryland, College Park. Md. 20742), $\&$ WEINBERG, E. S. Effects of chlordiazepoxide on scheduleinduced water and alcohol consumption in the squirrel monkey. Psychopharmacologia (Berlin), 1975, 40. 319-328.

Befcham, I. J., \& Handley, S. L. (Pharmacol. Labs.. Dept. of Pharmacy, Univ. of Aston. Birmingham B4 ET. England). Potentiation of catalepsy induced by narcotic agents during Haffner's test for analgesia. Psychopharmacologia (Berlin), 1974. 40. 157-164.

Benkert, O. (Psychiatrische Klinik der Universitat Munchen, D-8000 Munchen 2. Nussbaumstr. 7. Fed. Rep. of Germany), GORDON. A.. \& MARTSCHKE. D. The comparison of thyrotropin releasing hormone. luteinising hormone-releasing hormone and placebo in depressive patients using a double-blind cross-over technique. Psychopharmacologia (Berlin), 1974, 40, 191-198.

Blozovski. D. (Laboratoire de Psychophysiologie, Universite Paris VI. Cedex 05. Paris. France), \& Bachevalier, J. Effect of atropine on behavioral arousal in the developing rat. Developmental Psychobiology, 1975, 8, 97-102.

Cacl. W. F. (Vanderbilt Univ., Nashville, Tenn. 37240), Freeman, B. J., \& Buchanan, D. C. Effects of differential rearing condition on heart rate conditioning and response suppression. Developmental Psychobiology, 1974, 8. 63-68.
Chesher, G. B. (Dept. of Pharmacol.. Univ. of Sydney, N.S.W., Australia 2006), \& JACKson. D. M. The effect of withdrawal from cannabis on pentylenetetrazol convulsive threshold in mice. Psychopharmacologia (Berlin), 1974, 40, 129-135.

Clemens, J. A. (Lilly Rsch. Labs., Eli Lilly \& Co.. Indianapolis. Ind. 46206), Smalstig, E. B., \& Sawyer, B. D. Antipsychotic drugs stimulate prolactin release. Psychopharmacologia (Berlin). 1974. 40, 123-127.

Colquhoun. W. P. (MRC Applied Psychol. Unit. Lab. of Exptl. Psychol., Univ. of Sussex. Brighton, Sussex, England), \& EDwards. R. S. Interaction of noise with alcohol on a task of sustained attention. Ergonomics, 1975, 18. 81-87.

Cox. T. (Univ. of Nottingham, Nottingham N67 2RD. England), \& TYE, N. The effects of amphetamine, inipramine and ICI 58.834 (Vivalan), a potential antidepressant, on unconditioned behaviour in rats. Psychopharmacologia (Berlin). 1975, 40, 297-304.

DAntzer, R. (I.N.R.A., Station de Pharmacologie, 180, chemin de Tournequeuille, Toulouse, France), \& RocA, M. Tranquilizing effects of diazepam in pigs subjected to a punishment procedure. Psychopharmacologia (Berlin), 1974, 40. 235-240.

Downey, D. J. (Univ. of Arizona, Tucson, Ariz. 85721). Statedependent learning with centrally and noncentrally active drugs. Bulletin of the Psychonomic Society, 1975, 5, 281-284.

Dureman, I. (Univ. of Uppsala, Uppsala, Sweden), \& Norrman, B. Clinical and experimental comparison of diazepam, chlorazepate and placebo. Psychopharmacologia (Berlin). 1975, 40. 279-284.

Fernandez, B., \& Ternes, J. W. (Caribbean Primate Rsch. Ctr., Univ. of Puerto Rico, Sabana Seca, Puerto Rico 00794). Conditioned aversion to morphine with lithium chloride in morphine-dependent rats. Bulletin of the Psychonomic Society. 1975, 5. 331-332.

Freund, G. (VA Hosp. \& Dept. of Med., Univ. of Florida, Gainesville, Fla. 32602). Normal shuttle box avoidance learning after chronic phenobarbital intoxication in mice. Psychopharmacologia (Berlin). 1974, 40, 199-203.

Gadusek, F. J., \& Kalat, J. W. (Duke Univ., Durham, N.C. 27706). Effects of scopolamine on retention of taste-aversion learning in rats. Physiological Psychology, 1975, 3. 130-132.

Gillin, J. C. (Lab. of Clin. Psychopharmacol., SMR, IRP, NIMH, St. Elizabeths Hosp.. Washington, D.C. 20032), Fram, D. H., Wyatt, R. J., Henkin, R. I., \& SNyder., F. L-histidine: Failure to affect the sleep-waking cycle in man. Psychopharmacologia (Berlin), 1975, 40. 305-311.

Harding. T. (Univ. Dept. of Psychiat.. Royal Edinburgh Hosp., Edinburgh EH10 5HF. Scotland). The effect of lysergic acid di-ethylamide on serum creatine kinase levels. Psychopharmacologia (Berlin), 1974, 40. 177-184.

HirschHorn. I. D. (Dept. of Pharmacol.. Med. Coll. of Virginia, Richmond, Va. 23298). \& Rosecrans, J. A. Studies on the time course and the effect of cholinergic and adrenergic receptor blockers on the stimulus effect of nicotine. Psychopharmacologia (Berlin), 1974, 40, 109-120.

Houser. V. P. (Psychotropic Drug Lab., VA Hosp., Perry Point, Md. 21902). Effects of chronic administration and withdrawal of d-amphetamine upon daily activity levels of squirrel monkeys. Bulletin of the Psychonomic Society, 1975, 5, 313-314.

Houser, V. P. (Psychotropic Drug Lab., VA Hosp., Perry Point, Md. 21902). The effects of $\Delta^{9}$-tetrahydrocannabinol upon fear-motivated behavior in squirrel monkeys. Physiological Psychology, 1975, 3, 157-161

Hughes, R. N. (Univ. of Canterbury, Christchurch 1. New Zealand), \& Greig, A. M. Spontaneous alternation in ferrets following treatment with scopolamine, chlordiazepoxide, and cafteine. Physiological Psychology, 1975, 3, 155-156.

Jerussi, T. P., \& Glick, S. D. (Dept. of Pharmacol.. Mt. Sinai 
Sch. of Med., New York, N.Y. 10029). A pomorphineinduced rotation in normal rats and interaction with unilateral caudate lesions. Psychopharmacologia (Berlin), 1975, 40, 329-334.

Jones, B. E. (Natl. Inst. on Drug Abuse, Addiction Rsch. Ctr., P.O. Box 12390, Lexington, Ky, 40511), \& PradA, J. A. Drug-seeking behavior during methadone maintenance. Psychopharmacologia (Berlin), 1975, 41, 7-10.

Kallman, W. M., \& IsaAC, W. (Univ. of Georgia, Athens, Ga. 30602). The effects of age and illumination on the doseresponse curves for three stimulants. Psychopharmacologia (Berlin), 1975, 40, 313-318.

Lamprecht, F., Ebert, M. H. (Lab. of Clin. Sci., Rm. 45239, Bldg. 10, NIMH, Bethesda, Md. 20014), Turek, I., \& Kopin, I. J. Serum dopamine-beta-hydroxylase in depressed patients and the effect of electroconvulsive shock treatment. Psychopharmacologia (Berlin), 1974, 40, 241-248.

Mc Kearney, J. W. (Worcester Fdtn. for Exptl. Biol., Shrewsbury, Mass. 01545), \& BarretT, J. E. Punished behavior: Increases in responding after $d$-amphetamine. Psychopharmacologia (Berlin), 1975, 41, 23-26.

Moskowitz, H. (Inst. of Transportation and Traffic Eng., UCLA, Los Angeles, Calif. 90024), \& McGlothlin, W. Effects of marihuana on auditory signal detection. Psychopharmacologia (Berlin), 1974, 40, 137-145.

Olton, D. S. (Johns Hopkins Univ., Baltimore, Md. 21218), Johnson, C. T., \& HowARD, E. Impairment of conditioned active avoidance in adult rats given corticosterone in infancy. Developmental Psychobiology, 1974, 8, 55-61.

Pakkenberg, H. (Kommunehospitalet, $\emptyset$ Farimagsgade 5 , Copenhagen, DK-1399, Denmark), \& Fog, R. Short-term effect of perphenazine enanthate on the rat brain. Psychopharmacologia (Berlin), 1974, 40, 165-169.

Pickens, R. (Psychiat. Rsch. Unit, Box 392 Mayo, Univ. of Minnesota, Minneapolis, Minn. 55455), \& Thompson, T. Intravenous preparations for self-administration of drugs by animals. American Psychologist, 1975, 30, 274-276.

Pillard, R. C. (Psychopharmacol. Lab., Div. of Psychiat., Boston Univ. Med. Sch., Boston, Mass. 02118), McNaIr, D. M., \& Fisher, S. Does marijuana enhance experimentally induced anxiety? Psychopharmacologia (Berlin), 1974, 40, 205-210.

Rhodus, D. M. (Dept. of Exptl. Psychol., Walter Reed Army Inst. of Rsch., Washington, D.C. 20012), Elsmore, T. F., \& Manning. F. J. Morphine and heroin effects of multiple fixed-interval schedule performance in rats. Psychopharmacologia (Berlin), 1974, 40, 147-155.

Siegel, R. K. (Depts. of Pharmacol. \& Psychiat., UCLA, Los Angeles, Calif. 90024), Brewster, J. M., \& JARVIK, M. E. An observational study of hallucinogen-induced behavior in unrestrained Macaca mulatta. Psychopharmacologia (Berlin), 1974, 40, 211-223.

SuödÉN, P.-O. (Neurophysiol. Lab., Ulleraker Hosp., Univ. of Uppsala, S-75017, Uppsala, Sweden), \& Söberberg, U. Long-lasting effects of prenatal 2,4,5-trichlorophenoxyacetic acid on open-field behavior in rats: Pre- and postnatal mediation. Physiological Psychology, 1975, 3, 175-178.

SofiA, R. D. (Wallace Labs., Dept. of Pharmacol. \& Toxicol., Cranbury, N.J. 08512), VassaR, H. B., \& КNоBloch, L. C. Comparative analgesic activity of various naturally occurring cannabinoids in mice and rats. Psychopharmacologia (Berlin), 1975, 40, 285-295.

Stern, J. A., Bremer, D. A. (Dept. of Psychiat., Washington Univ. Med. Sch., St. Louis, Mo. 63110), \& McClure, J. Analysis of eye movements and blinks during reading: Effects of Valium. Psychopharmacologia (Berlin), 1974, 40, 171-175.

TAYlOR, M. (Univ. Coll. of North Wales, Bangor, Caernarvonshire, North Wales), Goudie, A. J., Mortimore, S., \& WhEELER, T. J. Comparison between behaviours elicited by high doses of amphetamine and fenfluramine: Implications for the concept of stereotypy. Psychopharmacologia (Berlin), 1974, 40, 249-258.

Ternes, J. W. (Caribbean Primate Rsch. Ctr., Univ. of Puerto Rico, Sabana Seca, Puerto Rico 00794). Conditioned aversion to morphine with naloxone. Bulletin of the Psychonomic Society, 1975, 5, 292-294.

Ternes, J. W. (Caribbean Primate Rsch. Ctr., Univ. of Puerto Rico, Sabana Seca, Puerto Rico 00794). Naloxoneinduced aversion to sucrose in morphine-dependent rats. Bulletin of the Psychonomic Society, 1975, 5, 311-312.

Ternes, J. W. (Caribbean Primate Rsch. Ctr., Univ. of Puerto Rico, Sabana Seco, Puerto Rico 00794). Induced preference for morphine in rats. Bulletin of the Psychonomic Society, 1975, 5, 315-316.

Viala, D. (Laboratoire de Neurophysiologie comparee, Universite de Paris VI, Paris, France), VAlin, A., \& Buser, P. Relationship between the "late reflex discharge" and locomotor movements in acute spinal cats and rabbits treated with DOPA. Archives Italiennes de Biologie, 1974, 112, 299-306.

Wilson, G. T. (Psychol. Clin., Rutgers Univ., New Brunswick, N.J. 08903), Leaf, R. C., \& Nathan, P. E. The aversive control of excessive alcohol consumption by chronic alcoholics in the laboratory setting. Journal of Applied Behavior Analysis, 1975, 8, 13-26.

\section{Stress Effects}

Bellingham, W. P. (Australian National Univ., Canberra, A.C.T. Australia 2600), Storlien, L. H., \& Stebulis,. R. J. Discrimination learning in the T-maze based on the secondary reinforcing effects of shock termination. Bulletin of the Psychonomic Society, 1975, 5, 327-328.

Paré, W. P. (Pavlovian Rsch. Lab., VA Hosp., Perry Point, Md. 21902), \& Livingston, A., JR. Shock predictability and plasma gastrin in the rat. Bulletin of the Psychonomic Society, 1975, 5. 289-291.

VIALA, D. (Laboratoire de Neurophysiologie comparee, Universite de Paris VI, Paris, France), Valin, A., \& Buser, P. Relationship between the "late reflex discharge" and locomotor movements in acute spinal cats and rabbits treated with DOPA. Archives Italiennes de Biologie, 1974, 112, 299-306.

WIKE, E. L. (Univ. of Kansas, Lawrence, Kans. 66045), Wolfe, V. L., \& Norsworthy, K. A. The effects of low frequency, whole body vibration on rats: Prolonged training, predictability, incremental training, and taste conditioning. Bulletin of the Psychonomic Society, 1975, 5, 333-335.

\section{Autonomic Effects}

Coles, M. G. H. (Univ. of Illinois, Champaign, Ill. 61820), Porges, S. W., \& Duncan-Johnson, C. C. Sex differences in performance and associated cardiac activity during a reaction time task. Physiological Psychology, 1975, 3, 141-143.

Gatchel, R. J. (Univ. of Texas, Arlington, Tex. 76019). Effects of interstimulus interval length on short- and long-term habituation of autonomic components of the orienting response. Physiological Psychology, 1975, 3, 133-136.

Krausman, D. T. (720 Rutland Ave., Baltimore, Md. 21205). Methods and procedures for monitoring and recording blood pressure. American Psychologist, 1975, 30, 285-294.

OвRIst, P. A. (Div. of Hith. Affairs, Sch. of Med., Dept. of Psychiat., Univ. of North Carolina, Chapel Hill, N.C. 27514), Gaebelein, C. J., \& Langer, A. W. Cardiovascular psychophysiology: Some contemporary methods of measurement. American Psychologist, 1975, 30, 277-284.

Patterson, M. M. (Dept. of Physiol., Kirksville Coll. of Osteopathic Med., Kirksville, Mo. 63501). Instrumentation and techniques in physiological psychology. American Psychologist, $1975,30,249-256$. 
Peretti, P. O. (Kennedy-King Coll., 6800 S. Wenderoth Ave. Chicago, Ill. 60621). Changes in galvanic skin response as affected by musical selection, sex, and academic discipline. Journal of Psychology, 1975, 89. 183-187.

Prokasy, W. F. (Univ. of Utah. Salt Lake City, Utah 84112). Williams. W. C., \& ClaRk. C. G. Skin conductance response conditioning with CS intensities equal to and greater than UCS intensity. Memon \& Cognition. 1975, 3, 277-281.

SANDler, H. (Chief. Biomed. Rsch. Div.. Mail Stop N-239-8.
NASA. Ames Rsch. Ctr.. Moffett Field, Calif. 94035), McCutcheon, E. P., Fryer, T. B., Rositano, S., Westbrook, R., \& HaRo, P. Recent NASA contributions to biomedical telemetry. American Psychologist, 1975, 30, 257-264.

Yaremko, R. M. (San Diego State Univ., San Diego, Calif. 92182). \& ButLer. M. C. Imaginal experience and attenuation of the galvanic skin response to shock. Bulletin of the Psychonomic Society, 1975. 5, 317-318. 